Jolanta ŚLEDZIŃSKA

Polskie Towarzystwo Turystyczno-Krajoznawcze, Warszawa

\title{
WĘDRUJ Z NAMI - SUKCES OGÓLNOPOLSKICH AKCJI PTTK
}

Liczba zarejestrowanych w Polsce organizacji pozarządowych od ponad 20 lat wciąż rośnie. Choć rok 1989 nie był początkiem sektora pozarządowego w naszym kraju, bo niektóre $\mathrm{z}$ organizacji, jak np. Polskie Towarzystwo Turystyczno-Krajoznawcze (PTTK) ${ }^{1}$, sięgają tradycjami roku 1883, to jednak zapoczątkował on okres przyspieszonego ich rozwoju. Niewystarczające finanse są niezmiennie od lat uważane przez działaczy pozarządowych za największy problem polskiego III sektora ${ }^{2}$. W badaniach przeprowadzanych w latach 1994 i 1995 brak funduszy był uznawany za główny problem w działalności sektora przez $47 \%$ działaczy (podczas gdy pozostałe mankamenty zostały wskazane przez zaledwie kilka procent respondentów).

${ }^{1}$ Polskie Towarzystwo Turystyczno-Krajoznawcze to najstarsze w Polsce stowarzyszenie skupiające turystów i krajoznawców. Powstało z połączenia Polskiego Towarzystwa Tatrzańskiego (1873 r.) i Polskiego Towarzystwa Krajoznawczego (1906 r.), których jest prawnym następcą oraz spadkobiercą ich tradycji, dorobku ideowego, a także majątku. Od 1950 r. PTTK rozwija, promuje i organizuje krajoznawstwo oraz turystykę powszechną i kwalifikowaną we wszystkich jej formach. Towarzystwo zrzesza 75 tys. członków, w tym 24355 dzieci i młodzieży działających w 2714 kołach i klubach, które tworzą 310 oddziałów (stan na 31.12.2011 r.).

2 III sektor to nazwa stosowana wobec ogółu organizacji pozarządowych. Określenie to, przeniesione z języka angielskiego (third sector), nawiązuje do koncepcji podziału dzielącego aktywność społeczno-gospodarczą nowoczesnych państw demokratycznych na trzy sektory. Tak więc obok instytucji państwa (administracji publicznej, sektora państwowego - pierwszego sektora) oraz podmiotów for-profit, nastawionych na zysk (biznes, sektor prywatny - drugiego sektora) istnieją organizacje, które nie są nastawione na zysk (non-profit) i nie stanowią elementu struktury państwa - są zatem trzecim sektorem. 
W kolejnych latach pozostał na pierwszym miejscu listy problemów i w roku 2001 wymieniało go 78\% respondentów, w $2006-73 \%$, a w $2008-61 \%$.

\section{Pojęcia podstawowe}

W tym rozdziale opracowania autorka przedstawia podstawowe pojęcia przyjęte $\mathrm{w}$ pracy. Jest to niezbędne, aby jednoznacznie zrozumieć treści zawarte w opracowaniu. W związku z licznie pojawiającymi się w literaturze definicjami i określeniami $\mathrm{w}$ niniejszej pracy przytoczone zostały jedynie te, które w najlepszy sposób wg autorki oddają istotę działalności PTTK.

"Stowarzyszenie" to wyraz podmiotowości jednoczących się w nim ludzi. Aby realizować swoje prawa ludzie jednoczą się w stowarzyszenia, które są ważnym ogniwem społeczeństwa obywatelskiego. Stanowią one obok instytucji samorządu terytorialnego i samorządów zawodowych istotne ogniwo samoorganizacji społeczeństwa.

„Turystyka" rozumiana jest szeroko jako sfera aktywności ludzkiej, społecznej obejmującej w sobie treść krajoznawcza, a w zakresie - sferę „działania społecznego". Poza sferą uregulowań prawnych, a właściwie w jej sensie, znajdują się także pojęcia, takie jak „braterstwo" i „solidarność", „normalność" i "radość". Do takiego ich rozumienia dochodzi w trakcie turystycznych wędrówek traktowanych nie jako produkt, ale jako „sens ludzkiej aktywności". W takie właśnie rozumienie podmiotowości turystyki wpisuje się działalność Polskiego Towarzystwa Turystyczno-Krajoznawczego.

"Sukces” to pomyślny wynik jakiegoś przedsięwzięcia. Sukces jest tym, czym go uczynisz. Sukces to powodzenie i spełnienie celu. Według PIETRASIŃSKIEGO $(1982$, s. 88) są to pojęcia zwykle ze sobą utożsamiane. „Sukces bywa rozumiany potocznie jako udanie się jakiejś sprawy, powodzenie" (PIETRASIŃSKI 1982, s. 88). Tak również podaje Nowy stownik języka polskiego: „Sukces to pomyślny wynik jakiegoś przedsięwzięcia" (SOBOL, red. 2002, s. 972). Angielskie słowo "success" ma z kolei następujące znaczenia: 1) stopień, miara powodzenia; 2) dokonanie czegoś na czym nam zależy.

„Sukces i powodzenie możemy rozpatrywać w kategoriach ilościowych i jakościowych. Rozpatrzenie kategorii ilościowej sukcesu i powodzenia jest rzeczą prostą. Subiektywnym wyznacznikiem sukcesu jest nasz indywidualny poziom aspiracji. W miarę odnoszenia sukcesów poziom ten rośnie

3 Podstawowe statystyki dotyczące działań pozarządowych w Polsce, Stowarzyszenie Klon-Jawor, 1996 (badanie przeprowadzane w 1994 i 1995) http://wiadomosci.ngo.pl/strona/459472.html (20.11.2011 r.). 
wraz z naszymi umiejętnościami i zdolnościami" (PIETRASIŃSKI 1982, s. 89). Tak więc, to co jest powodzeniem dla jednych, może być sukcesem dla innych i odwrotnie.

Przyjrzyjmy się również określeniom: „przedsięwzięcie - projekt plan", inicjatywa, pomysł i/lub skupiony wokół nich ruch społeczności. Pomysł oznacza znalezienie sposobu na dalsze działanie, np. napisanie tekstu, wykonanie skoku, rozwiązanie problemu. KOPALIŃSKI (2006) określa go następująco: „Program, projekt (działań, prac, zadań, celów) to plan postępowania, spis celów do osiągnięcia, kolejne etapy przedsięwzięcia".

W PTTK termin „projekt” rozumiany jest jako przedsięwzięcie realizowane według określonego harmonogramu, prowadzącego do osiągnięcia określonego celu. Słowo "projekt” zyskuje w ostatnich latach coraz większą popularność, a wynika to głównie z przyjęcia nazewnictwa stosowanego w dokumentach UE. Określenie to zaczyna coraz częściej wypierać dotychczas używane słowo „akcja”.

"Akcja" - działanie, działalność, ruch, czynność; zbiorowe wystąpienie, zespołowe przedsięwzięcie (KOPALIŃSKI 2006). W Polskim Towarzystwie Turystyczno-Krajoznawczym jest to pojęcie odnoszące się do jedno-, dwurocznych działań tematycznych podejmowanych z inicjatywy Zarządu Głównego PTTK, a realizowanych przez różne środowiska (niekoniecznie PTTK) na terenie całego kraju.

„Projekty” są jednorazowym wysiłkiem skierowanym na dostarczenie produktu, który jest pod wieloma względami wyjątkowej natury. Potrzebne są spore umiejętności i doświadczenie do wykrycia potencjalnych problemów i ryzyk, aby zaplanować działania, czas, ludzi, sprzęt, materiały i potrzebne pieniądze (www.spmp.org.pl). Projekt to wreszcie pewien systematyczny proces mający na celu osiągnięcie jakiegoś wyraźnego celu. Ten "system” składa się z fazy planowania poprzedzającej okres „wykonywania” i jest powtarzany na każdym poziomie szczegółowości. Te dwie "fazy” są źródłem cyklu życia projektu. Zarządzanie projektami jest procesem zarządzania przebiegiem projektu (www.spmp.org.pl).

"Stowarzyszenie" to organizacja społeczna, którą może powołać dowolna grupa osób. Osoby te muszą jedynie mieć wspólnie określone cele lub, ewentualnie - wspólne zainteresowania. Główną cechą stowarzyszenia jest to, że działa w celach niezarobkowych i funkcjonuje na zasadzie dobrowolności. Jest trwałe i samorządne. Samodzielnie określa swoje cele, a także struktury oraz program działania. Może także uchwalać swoje wewnętrzne akty, które dotyczyć będa jego działalności. Cała działalność zasadniczo opiera się na pracy społecznej członków stowarzyszenia (www.cotojest.info). 
Ustawowa definicja organizacji, jaka jest stowarzyszenie znajduje sie $\mathrm{w}$ art. 2 ustawy Prawo o stowarzyszeniach. Zgodnie z nim stowarzyszenie to dobrowolne, samorzadne, trwałe zrzeszenie o celach niezarobkowych ${ }^{4}$. Koleina cecha stowarzyszenia jest jego samorzadność oznaczająca autonomie celów, struktury organizacyinej, zasad działania, niezależność od podmiotów zewnętrznych. Przejawem samorządności stowarzyszenia jest swoboda w określaniu swoich uchwał i aktów wewnętrznych dotyczących prowadzonej działalności. Cecha ta odróżnia stowarzyszenia od partii politycznych (SUSKI 2002).

\section{Organizacje pozarządowe a pozyskiwanie środków na ich działalność}

Od początku 2007 do końca marca 2012 r. beneficjentami funduszy Unii Europejskiej zostało 3126 spośród niemal 87,8 tys. fundacji i stowarzyszeń, czyli zaledwie $4 \%$ ich ogólnej liczby. Podpisały one umowy na realizację 7,5 tys. projektów o łącznej wartości 5,9 mld zł. Ponad połowa tej kwoty trafiła (lub w najbliższym czasie trafi) do 111 organizacji - do każdej z nich co najmniej $10 \mathrm{mln}$ zł. Z kolei ok. 1000 fundacji i stowarzyszeń musiało zadowolić się dofinansowaniem UE dla projektów o znacznie niższej wartości - nieprzekraczającej 50 tys. zł. Jeśli wartość projektów unijnych realizowanych przez organizacje pozarządowe przedstawimy w przeliczeniu na jedną organizację działającą na danym terenie, okaże się, że liderami w pozyskiwaniu funduszy unijnych są fundacje i stowarzyszenia z obszarów wschodniej Polski, a głównie z województw: świętokrzyskiego, lubelskiego i podlaskiego. Średnia wartość projektów unijnych przypadających na jedną organizację z tych trzech regionów to ponad 100 tys. zł, czyli dwukrotnie więcej niż na organizację z Mazowsza, a niemal trzykrotnie więcej niż np. z Dolnego Śląska ${ }^{5}$.

Przez wiele lat Polskie Towarzystwo Turystyczno-Krajoznawcze pozyskując środki z różnych resortów realizowało cele statutowe na właściwym poziomie merytorycznym. Niestety z roku na rok zadań statutowych, które można zrealizować dzięki wsparciu zewnętrznemu jest coraz mniej. Zaznacza się też tendencja zmniejszania ilości środków przeznaczonych na tradycyjne i ważne działania, o dofinansowanie których występowało Towarzyst-

4 Pojęcie „zrzeszenie” nie zostało zdefiniowane w żadnej ustawie, dlatego przyjmuje się znaczenie nadane zrzeszeniom $\mathrm{w}$ socjologii.

${ }^{5} \mathrm{Na}$ podstawie danych Ministerstwa Rozwoju Regionalnego KSI (SIMIK 07-13) według stanu na 31 marca 2012 r., a także www.mojapolis.pl/web/guest/kiosk (30.03.2012). 
wo (np. znakowanie szlaków turystycznych)6 ${ }^{6}$. Po wejściu Polski do UE przez kilka lat istniały dodatkowe możliwości pozyskiwania środków dzięki różnym programom pomocowym. Warunkiem niezbędnym realizacji programów dofinansowujących przedsięwzięcia o charakterze programowym było adresowanie ich do całego społeczeństwa. Ważnym i pozytywnym efektem aplikowania o środki zewnętrzne była możliwość przygotowania w jednostkach terenowych (oddziałach) kadry działaczy - pracowników, którzy przez minione lata nabyli doświadczenia w pisaniu wniosków konkursowych. Pozyskiwanie środków zewnętrznych przez PTTK warunkuje wypełnianie ogólnospołecznej misji towarzystwa. W dużej mierze decyduje również o wewnętrznym umacnianiu się organizacji, kształtowaniu marki oraz pozycji na rynku turystycznym, co w warunkach ostrej konkurencji wydaje się być niezbędne. Niezwykle ważnym miernikiem wykorzystania zewnętrznych środków finansowych, o które organizacja ubiega się w drodze konkursów, jest efekt społeczny związany z ciągłym umacnianiem PTTK jako lidera w:

- kształtowaniu postaw proekologicznych;

- propagowaniu zrównoważonego rozwoju,

- zakresie edukacji krajoznawczej dzieci i młodzieży;

- zakresie turystyki społecznej, ze szczególnym uwzględnieniem osób niepełnosprawnych.

Organizacje społeczne pełnią czasami funkcje administracyjne, zastępując administrację rządową $\mathrm{w}$ niektórych ściśle określonych sferach życia publicznego. Przykładem może być Polski Związek Łowiecki, który zrzesza myśliwych, zarządza gospodarką łowiecka, wprowadza limity odstrzałów zwierzyny łownej, kontroluje przestrzeganie okresów ochronnych, prowadzi hodowlę i dokarmianie dzikich zwierząt. Polski Związek Wędkarski ma podobne zadania $\mathrm{w}$ zakresie połowu ryb słodkowodnych i wydawania odpowiednich zezwoleń. Nieco inaczej funkcję swoją realizuje PTTK.

„Celami statutowymi PTTK są działania ze sfery zadań publicznych w zakresie:

1) krzewienia turystyki i krajoznawstwa oraz aktywnych form wypoczynku dzieci i młodzieży, szczególnie w postaci wędrownictwa indywidualnego i grupowego, organizacji rajdów, złazów, zlotów, spływów, rejsów oraz kolonii i obozów;

2) podtrzymywania tradycji narodowej, pielęgnowania polskości oraz rozwoju świadomości narodowej, obywatelskiej i kulturowej, w tym poprzez

${ }^{6}$ W latach 2002-2010 PTTK otrzymywało z Ministerstwo Sportu i Turystyki na odnowienie szlaków $1 / 3$ funduszy w stosunku do ogólnego zapotrzebowania, natomiast w 2011 r. dofinansowanie na odnowienie szlaków wyniosło $0 \mathrm{zł}$. 
współdziałanie z towarzystwami i organizacjami skupiającymi i opiekującym się Polakami oraz dziedzictwem kultury polskiej za granica;

3) nauki, edukacji, oświaty i wychowania dzieci i młodzieży, szczególnie poprzez kształtowanie postaw społecznych, upowszechniania wiedzy o przeszłości, współczesności i perspektywach rozwoju Polski, szerzenia kultury turystyki i zapoznania z poznawczymi, wypoczynkowymi i zdrowotnymi walorami wędrownictwa;

4) ekologii i ochrony zwierząt, ochrony dziedzictwa przyrodniczego oraz troski o racjonalne wykorzystywanie zasobów przyrody;

5) upowszechniania wiedzy i umiejętności na rzecz obronności państwa, szczególnie poprzez opiekę nad miejscami pamięci narodowej i organizację imprez turystycznych związanych z poznawaniem historii oręża polskiego, a także popierania wszelkich form wypoczynku służącego rozwojowi sprawności i kultury fizycznej."

W niniejszym opracowaniu odniesiono się do akcji (projektów) zrealizowanych przez PTTK w latach 2002-2012. Tabela 1 jest syntetyczną charakterystyką akcji (projektów) podejmowanych w latach 2002-2012. Przedstawiono w niej m.in. czas trwania akcji, podstawowe cele, hasło oraz mierzalne efekty (liczba uczestników, publikacje itp.). Projekty te Towarzystwo realizowało przede wszystkim w ramach własnego budżetu, przy niewielkim wsparciu Polskiej Organizacji Turystycznej, Lasów Państwowych i Gaz de France.

Lata następne to próba pozyskiwania środków z różnych źródeł zewnętrznych, które pozwalały organizować te przedsięwzięcia w szerszym zakresie, m.in.:

- środki przejściowe Unii Europejskiej (UE) - Rok szlaków turystycznych (2007) i Turystyka dla wszystkich (2008);

- Program Operacyjny Fundusz Inicjatyw Obywatelskich (PO FiO) Poznajemy ojczyznę i Turystyka dla wszystkich (2006), Przyroda uczy najpiękniej (2008) ${ }^{8}$;

- Narodowy Fundusz Ochrony Środowiska i Gospodarki Wodnej (NFOŚ iGW) - Edukacja ekologiczna na szlakach turystycznych (2007), Edukacja kadry programowej Natura 2000 dwie edycje w 2007 i 2009 r., Przyroda uczy najpiękniej (2008/2009).

\footnotetext{
${ }^{7}$ Statut PTTK z 2009 r. - www.pttk.pl/pttk/przepisy/statut_pttk.pdf (20.11.2011).

8 Odkąd zmieniły się zasady PO FIO, PTTK pomimo pozytywnej i wysokiej oceny merytorycznej wniosków nie otrzymuje dofinansowania na ich realizację, gdyż ma odejmowane punkty za miejsce siedziby - Warszawę, a także za fakt, że jest organizacją działającą dłużej niż trzy lata. Preferowane są małe organizacje, z niedużych miejscowości, działające do trzech lat [przypis autorki].
}

154 WARSZTATY Z GEOGRAFII TURYZMU 
Tabela 1. Akcje (projekty) zrealizowane przez Polskie towarzystwo Turystyczno-Krajoznawcze w latach 2002-2012

\begin{tabular}{|c|c|}
\hline \multicolumn{2}{|r|}{ ROK 2002} \\
\hline [1] & {$[2]$} \\
\hline Akcja & Międzynarodowy Rok Gór (zainicjowany przez Organizację Narodów Zjednoczonych). \\
\hline Hasło/przesłanie & „Wszyscy jesteśmy ludźmi gór”. \\
\hline Cel akcji & Podejmowanie różnorodnych działań na rzecz zrównoważonego rozwoju obszarów górskich. \\
\hline Adresat & Osoby zainteresowane turystyką górska, organizacje działające w obrębie gór, gestorzy bazy, samorządy. \\
\hline Zasięg & Ogólnopolski, w przedsięwzięciach wzięły udział wszystkie województwa. \\
\hline $\begin{array}{l}\text { Imprezy/działania/ } \\
\text { konferencje/ publi- } \\
\text { kacje centralne }\end{array}$ & $\begin{array}{l}\text { - Pierwsze równoczesne przejście Głównego Szlaku Górskiego (Świeradów Zdój-Wołosate; } 25.05 .2002 \text { r. } \\
\text { - Spotkania na szczytach: bicie rekordu Guinessa (14.08.2002). } \\
\text { - Międzynarodowe spotkanie organizacji turystycznych na Równicy. }\end{array}$ \\
\hline Efekty mierzalne & $\begin{array}{l}\text { - Po polskich górach w tym dniu wędrowało } 8000 \text { osób. } \\
\text { - Ponad } 10 \text { tys. turystów w dniu tym zdobyło } 108 \text { szczytów - od Góry Słowiańskich Bogów w zachodniopo- } \\
\text { morskim ( } 52 \text { m. n.p.m.), po najwyższy szczyt Rysy (2499 m n.p.m.) w Tatrach. } \\
\text { - Klub Czeskich Turystów, Klub Słowackich Turystów i Polskie Towarzystwo Turystyczno-Krajoznawcze. } \\
\text { - Opracowanie wspólnej koncepcji zagospodarowania turystycznego górskich obszarów przygranicznych. }\end{array}$ \\
\hline $\begin{array}{l}\text { Działania uzu- } \\
\text { pełniające (semi- } \\
\text { naria, konkursy, } \\
\text { wystawy i inne) }\end{array}$ & $\begin{array}{l}\text { - Seminarium „Aktualny stan i zadania przewodnictwa górskiego”; (Sucha Beskidzka). } \\
\text { - Sympozjum górskie „Góry udostępniać, aby chronić?”(COTG PTTK). } \\
\text { - Wystawa fotograficzna „Granie i połoniny” (CFK PTTK). } \\
\text { - Zorganizowano siedem wystaw o tematyce górskiej w galerii COTG PTTK. } \\
\text { - Konkurs plastyczny „Rodzinna wędrówka górska”(Komisja Działalności w miejscu Zamieszkania ZG PTTK). }\end{array}$ \\
\hline $\begin{array}{l}\text { Imprezy środo- } \\
\text { wiskowe i oddzia- } \\
\text { łowe }\end{array}$ & $\begin{array}{l}\text { Podejmowano wiele inicjatyw, nie prowadzono ewidencji; można wymienić: } \\
\text { - Rajd Młodzieży szkolnej w Górach Świętokrzyskich - } 500 \text { osób. } \\
\text { - Zlot Turystów Górskich w Żywcu - } 450 \text { osób. } \\
\text { - XXXI Centralny Zlot Turystów Wojskowych w Żywcu - } 2509 \text { osób. } \\
\text { - Rajd szlakami Jerzego Kukuczki w Istebnej - } 250 \text { osób. }\end{array}$ \\
\hline Finansowanie & Budżet ZG PTTK, a imprezy oddziałowe przez Oddziały PTTK i współpracujące z nimi samorządy. \\
\hline \multicolumn{2}{|r|}{ ROK 2003} \\
\hline Akcja & Europejski Rok Osób Niepełnosprawnych (ogłoszony przez Radę Unii Europejskiej). \\
\hline Hasło/przesłanie & „Razem z PTTK będzie sprawniej”. \\
\hline Cel akcji & $\begin{array}{l}\text { - Popularyzacja turystyki osób niepełnosprawnych. } \\
\text { - Kształtowanie właściwych postaw społecznych wobec osób niepełnosprawnych, co jest konieczne dla ich } \\
\text { integracji społecznej. } \\
\text { - Popularyzowanie aktywnych i integracyjnych form spędzania wolnego czasu przez osoby niepełnosprawne. } \\
\text { - Integracja i aktywizacja turystyczna osób niepełnosprawnych. }\end{array}$ \\
\hline Adresat & $\begin{array}{l}\text { Osoby niepełnosprawne, uczelnie działajace w obrębie turystyki osób niepełnosprawnych, gestorzy bazy, } \\
\text { władze administracyjne i samorządowe. }\end{array}$ \\
\hline Zasięg & Ogólnopolski (nie ma informacji nt. tego, ile środowisk wzięło udział). \\
\hline $\begin{array}{l}\text { Imprezy/działania/ } \\
\text { konferencje/ publi- } \\
\text { kacje centralne }\end{array}$ & $\begin{array}{l}\text { Opracowano i rozesłano do wszystkich jednostek PTTK specjalny Apel Rady Turystyki Osób Niepełnospraw- } \\
\text { nych ZG PTTK o podjęciu prac i właczenie do programów imprez zadań dla osób niepełnosprawnych; } \\
\text { - Ogólnopolski Sejmik „Razem z PTTK będzie sprawniej”. }\end{array}$ \\
\hline Efekty mierzalne & $\begin{array}{l}\text { - Ogólnopolski Sejmik „Razem z PTTK będzie sprawniej” - wzięło w nim udział } 160 \text { osób. } \\
\text { - Rada ds. osób niepełnosprawnych była organizatorem sesji nt. „Rekreacja i turystyka osób niepełnospraw- } \\
\text { nych”, która odbyła się 26-27 września } 2003 \text { r. we Wrockawiu w ramach Międzynarodowej Konferencji Nau- } \\
\text { kowej „Aktywność ruchowa osób niepełnosprawnych”. }\end{array}$ \\
\hline $\begin{array}{l}\text { Działania uzu- } \\
\text { pełniające (semi- } \\
\text { naria, konkursy, } \\
\text { wystawy i inne) }\end{array}$ & $\begin{array}{l}\text { - Komisja Górskiej Turystyki Jeździeckiej zorganizuje dla dzieci niewidomych i słabo widzących obozy inte- } \\
\text { gracyjne z dziećmi z Domu Dziecka. } \\
\text { - Komisja Przewodnicka od lat organizuje szkolenia przewodników dla wycieczek turystów niewidomych. } \\
\text { Wspólnie z Rada ds. TON zorganizowała sesję w Laskach nt. „Metodyka oprowadzania wycieczek dla osób } \\
\text { niewidomych”. } \\
\text { - Komisja Turystyki Pieszej podjęła uchwałę znoszącą limity czasowe w zdobywaniu odznak Turystyki Pieszej } \\
\text { przez osoby niepełnosprawne. } \\
\text { - Komisja Krajoznawcza zmodyfikowała regulamin Odznaki Krajoznawczej znosząc limit czasu na zdobywanie } \\
\text { poszczególnych stopni. }\end{array}$ \\
\hline
\end{tabular}




\begin{tabular}{|c|c|}
\hline$[1]$ & {$[2]$} \\
\hline $\begin{array}{l}\text { Imprezy środo- } \\
\text { wiskowe i oddzia- } \\
\text { łowe }\end{array}$ & $\begin{array}{l}\text { - Ogólnopolski IX Rajd Podlaski „Sprawni inaczej - powitanie lata”. } \\
\text { - I Spółdzielczy Piknik Integracyjny Osób Niepełnosprawnych w Siewierzu (300 osób). } \\
\text { - Szkolenie przewodników PTTK z zakresu metodyki oprowadzania osób ociemniałych i niedowidzących. }\end{array}$ \\
\hline Finansowanie & Budżet ZG PTTK. \\
\hline \multicolumn{2}{|r|}{$\begin{array}{c}\text { ROK } 2003 \\
\text { (od } 25.05 \text { do } 28.09 .2003 \text { r.); w niektórych środowiskach związanych z turystyką kontynuowano w } 2004 \text { r. }\end{array}$} \\
\hline Akcja & Spotkania u źródeł rzek (ZG PTTK). \\
\hline Hasło/przesłanie & „Z PTTK u tysiąca źródel”. \\
\hline Cel akcji & Dotarcie oraz oznakowanie źródeł rzek, potoków w Polsce, uporządkowanie ich, odpowiednie oznaczenie. \\
\hline Adresat & Członkowie PTTK. Współpraca z lokalnymi władzami samorządowymi i administracyjnymi. \\
\hline Zasięg & 15 województw - 41 oddziałów PTTK. \\
\hline $\begin{array}{l}\text { Imprezy/działania/ } \\
\text { konferencje/ publi- } \\
\text { kacje centralne }\end{array}$ & $\begin{array}{l}\text { - Wyszukanie źródeł rzek i rzeczek na terenie działania oddziałów, oznakowanie owych źródeł. } \\
\text { - W razie potrzeby dokonanie niezbędnych prac porządkowych lub zgłoszenie konieczności większych prac do } \\
\text { odpowiednich władz. } \\
\text { - Zorganizowanie w tym okresie zlotów, złazów do źródeł rzek. } \\
\text { - Podjęcie wspólnie z lokalnymi mediami akcji popularyzatorskiej i promocyjnej. } \\
\text { - Zgłoszenie do ZG PTTK informacji o podjętych działaniach, które będą podstawą raportu. }\end{array}$ \\
\hline Efekty mierzalne & $\begin{array}{l}\text { Z meldunków wynika, że oddziały zorganizowały } 80 \text { imprez, w których uczestniczyły } 6343 \text { osoby. } \\
\text { Zinwentaryzowano ponad } 100 \text { źródeł rzek i rzeczek, posprzątano ich tereny i odpowiednio oznakowano. }\end{array}$ \\
\hline $\begin{array}{l}\text { Działania uzu- } \\
\text { pełniajace (semi- } \\
\text { naria, konkursy, } \\
\text { wystawy i inne) }\end{array}$ & $\begin{array}{l}\text { - Konkurs plastyczny „Spotkanie u źródeł rzek”. } \\
\text { - Konkurs fotograficzny „Spotkanie u źródeł rzek”. } \\
\text { - Konkurs z „Poznaj Świat”, polegający na odkrywaniu źródeł nie tylko rzek Polski, ale i świata; rywalizacja } \\
\text { polegała na dotarciu do źródła wybranej rzeki i opisaniu odkrytego miejsca. }\end{array}$ \\
\hline $\begin{array}{l}\text { Imprezy środowis- } \\
\text { kowe i oddziałowe }\end{array}$ & $\begin{array}{l}\text { W roku } 2003 \text { oddziały zorganizowały } 80 \text { imprez - rajdy, wycieczki krajoznawcze; w większości uczestniczyła } \\
\text { w nich młodzież szkolna. }\end{array}$ \\
\hline Finansowanie & Polska Organizacja Turystyczna - 8 tys. zł, budżet ZG PTTK - 6 tys. zł, wpłaty uczestników - 16 tys. zł. \\
\hline \multicolumn{2}{|r|}{$\begin{array}{l}\text { Rok } 2004 \\
\text { (od } 4.04 \text { do } 24.10 . \text { ) }\end{array}$} \\
\hline Akcja & Rok schronisk górskich PTTK (inicjatywa XV Walnego Zjazdu PTTK). \\
\hline Hasło/przesłanie & - \\
\hline Cel akcji & $\begin{array}{l}\text { Strategiczny: ugruntowanie przekonania o niezbędności schronisk dla funkcjonowania turystyki. Popularyzacja } \\
\text { (promocja) schronisk PTTK w społeczeństwie. Zachęcanie do częstszego korzystania z naszych schronisk. } \\
\text { Wytworzenie mody na chodzenie do schronisk jako celu wycieczek. Podniesienie standardu wyposażenia i ob- } \\
\text { sługi w schroniskach m.in. poprzez wymuszanie na dzierżawcach wprowadzenia szerszej oferty gastronomicz- } \\
\text { nej, organizacji pobytów, usług dodatkowych (parkingi, rozrywki, itp.). }\end{array}$ \\
\hline Adresat & $\begin{array}{l}\text { Adresatami programu Roku byli gospodarze schronisk i „górskie” oddziały PTTK. Pierwsi będą odgrywać rolę } \\
\text { gospodarzy kilkudziesięciu spotkań, drudzy będą organizatorami imprez turystycznych, których miejscem } \\
\text { kulminacji lub finału będzie wybrane schronisko. Producent czekolady „Milka” był współorganizatorem spotkań. }\end{array}$ \\
\hline Zasięg & Obchodami objęto 33 schroniska górskie PTTK, w tym 10 z nich w Małopolsce. \\
\hline $\begin{array}{l}\text { Imprezy/działania/ } \\
\text { konferencje/ publi- } \\
\text { kacje centralne }\end{array}$ & $\begin{array}{l}\text { Co tydzień (poza miesiącami wakacyjnymi) inne schronisko organizowało prezentację, piknik, występy, } \\
\text { konkursy. Prezentowano specjalność kuchni, kiermasze, imprezy oddziału, wystawy, zawody sportowo-rekrea- } \\
\text { cyjne (rowery górskie, nartorolki, wspinaczka, pokazy paralotni, skoki, spływy, zjazdy itp.). }\end{array}$ \\
\hline Efekty mierzalne & $\begin{array}{l}\text { - } 33 \text { schroniska PTTK (od Sudetów, przez Beskidy, Tatry do Bieszczad) to } 33 \text { spotkania, w których wzięło } \\
\text { udział } 5000 \text { osób. } \\
\text { - We współpracy z „Milka” wydano czekolady - specjalne opakowanie „Rodzima Przygoda”, w których był } \\
\text { regulamin Roku Schronisk Górskich; } \\
\text { - Wydano } 35 \text { folderów o historii każdego z promowanych schronisk (łączny nakład } 20 \text { tys. egz.). } \\
\text { - Wydano i rozpropagowano } 22 \text { tys. ksiażeczek GOT - w nich informacja o „Roku schronisk górskich”. }\end{array}$ \\
\hline $\begin{array}{l}\text { Działania uzu- } \\
\text { pełniające (semi- } \\
\text { naria, konkursy, } \\
\text { wystawy i inne) }\end{array}$ & $\begin{array}{l}\text { - Turyści nocujacy od } 1 \text { kwietnia } 2004 \text { do } 30 \text { czerwca } 2005 \text { r. w schroniskach PTTK mogli wziąć udział w kon- } \\
\text { kursie „Pod dachem schroniska górskiego PTTK”. } \\
\text { - Na szczycie Lubania w Gorcach odsłonięto pamiątkową tablicę poświęconą schroniskom górskim niszczo- } \\
\text { nym podczas II wojny światowej i utraconym na Kresach Wschodnich II Rzeczypospolitej. } \\
\text { - Spotkania z przedstawicielami zarządów województw, starostw, gmin i przedstawicielami mediów były okazją } \\
\text { do ukazania działalności PTTK jako prężnej organizacji dbającej o swój majątek w postaci schronisk o coraz } \\
\text { lepszym standardzie, w tym ekologiczne. }\end{array}$ \\
\hline
\end{tabular}

156 | WARSZTATY Z GEOGRAFII TURYZMU 


\begin{tabular}{|c|c|}
\hline$[1]$ & [2] \\
\hline $\begin{array}{l}\text { Imprezy środo- } \\
\text { wiskowe i oddzia- } \\
\text { łowe }\end{array}$ & $\begin{array}{l}\text { Oddziały włączyły się do akcji poprzez współorganizację tych spotkań, planowanie rajdów i wycieczek dla } \\
\text { mieszkańców miejscowości podgórskich. Wspólne wyjścia w góry - zgodnie z wcześniej przyjętym harmo- } \\
\text { nogramem. }\end{array}$ \\
\hline Finansowanie & $\begin{array}{l}\text { Spółki PTTK: Karpaty, Sudety i Bieszczady. Sponsor „Milka” - } 1 \text { mln sztuk czekolad rozdanych na szlaku, } \\
\text { przy okazji spotkań przy schroniskach. }\end{array}$ \\
\hline \multicolumn{2}{|r|}{$\begin{array}{c}\text { Rok } 2005 \\
\text { (kwiecień-maj); akcję kontynowano w } 2006 \text { r. }\end{array}$} \\
\hline Akcja & Sadzimy las (inicjatywa PTTK i Dyrekcji Lasów Państwowych). \\
\hline Hasło/przesłanie & - \\
\hline Cel akcji & $\begin{array}{l}\text { Akcja „Sadzimy las” miała na celu nie tylko powiększenie terenów leśnych, ale - co mocno podkreślano - walory } \\
\text { edukacyjno-wychowawcze. Ponadto ważne było zwrócenie uwagi na szczególną rolę lasów w uprawianiu } \\
\text { turystyki, ukazania jego walorów zdrowotnych i przyrodniczych oraz jego wpływu na regenerację sił fizycznych } \\
\text { i psychicznych. }\end{array}$ \\
\hline Adresat & $\begin{array}{l}\text { Inicjatywa edukacyjno-wychowawcza skierowana głównie do młodego pokolenia turystów; wspólnie z Dyrekcją } \\
\text { Lasów Państwowych. }\end{array}$ \\
\hline Zasięg & Ogólnopolska (wzięło w niej udział tylko kilkanaście oddziałów). \\
\hline $\begin{array}{l}\text { Imprezy/działania/ } \\
\text { konferencje/ publi- } \\
\text { kacje centralne }\end{array}$ & $\begin{array}{l}\text { Szczegółowa realizacja tego zadania zależała od pomysłowości poszczególnych oddziałów PTTK, ich możli- } \\
\text { wości organizacyjnych i kontaktów ze służbami leśnymi. }\end{array}$ \\
\hline Efekty mierzalne & $\begin{array}{l}\text { Akcja przeprowadzona była w ramach planowanych zalesień pod nadzorem i specjalnym instruktażem pracow- } \\
\text { ników poszczególnych nadleśnictw. }\end{array}$ \\
\hline $\begin{array}{l}\text { Działania uzu- } \\
\text { pelniajace (semi- } \\
\text { naria, konkursy, } \\
\text { wystawy i inne) }\end{array}$ & Wszystkie przedsięwzięcia były zaplanowane w terenie. \\
\hline $\begin{array}{l}\text { Imprezy środo- } \\
\text { wiskowe i oddzia- } \\
\text { łowe }\end{array}$ & $\begin{array}{l}\text { - W } 2005 \text { r. do sadzenia lasu przystapiły jednostki PTTK z Oddziału PTTK w Prudniku, Brodnicy, Rawiczu, } \\
\text { Bielsku-Białej, z Koła PTTK „Horyzont” w Solcu Kujawskim i Toruniu. } \\
\text { - W } 2006 \text { r. Oddział PTTK w Radlinie, , Zagłębie Miedziowe” w Lubinie, Bielsku-Białej i Solcu Kujawskim oraz } \\
\text { Klub Krajoznawczo-Turystyczny PTTK „Róża Wiatrów" przy Ośrodku Sportu i Rekreacji w Łukowie, SKKT- } \\
\text { PTTK „Compass” przy Zespole Szkoły Podstawowej i Gimnazjum w Zakliczynie. }\end{array}$ \\
\hline Finansowanie & Sponsor - Gaz de France. Budżet ZG PTTK. \\
\hline \multicolumn{2}{|r|}{ Rok 2006 i 2008} \\
\hline Akcja & Turystyka dla wszystkich (inicjatywa PTTK). \\
\hline Hasło/przesłanie & Turystyka i krajoznawstwo niepełnosprawnych, czyli „Wędrować każdy może”. \\
\hline Cel akcji & $\begin{array}{l}\text { Celem projektu było upowszechnienie wśród osób niepełnosprawnych aktywnych form spędzania wolnego } \\
\text { czasu poprzez turystykę i krajoznawstwo. Zweryfikowanie dostępności infrastruktury turystycznej dla potrzeb } \\
\text { osób z różnymi rodzajami niepełnosprawności. }\end{array}$ \\
\hline Adresat & $\begin{array}{l}\text { Gestorzy infrastruktury turystycznej, jednostki samorządowe i administracyjne, organizacje/ stowarzyszenia } \\
\text { współpracujace z osobami niepełnosprawnymi, uczelnie wyższe, osoby z różnymi niepełno sprawnościami ich } \\
\text { rodziny. }\end{array}$ \\
\hline Zasięg & $\begin{array}{l}\text { - W } 2006 \text { r. projekt pilotażowy na terenie trzech województw: mazowieckiego, łódzkiego i podlaskiego. } \\
\text { - W } 2008 \text { r. cały kraj - w } 16 \text { województwach } 16 \text { koordynatorów regionalnych, } 500 \text { wolontariuszy. }\end{array}$ \\
\hline $\begin{array}{l}\text { Imprezy/działania/ } \\
\text { konferencje/ publi- } \\
\text { kacje centralne }\end{array}$ & $\begin{array}{l}\text { Projekt obejmował następujące rodzaje działań: } \\
\text { - zebranie danych na podstawie ujednoliconych ankiet i formularzy na temat dostępności obiektów infrastruk- } \\
\text { - tury; } \\
\text { - } \text { weryfikację i przetworzenie danych; } \\
\text { - umieszczenie ich w ogólnopolskiej bazie danych; } \\
\text { - wsparcie bazy danych wydawnictwami i publikacjami; } \\
\text { - prowadzenie kampanii informacyjno-promocyjnej; } \\
\text { - } \text { zorganizowanie konferencji popularnonaukowej „Rola krajoznawstwa i turystyki w życiu osób niepełno- } \\
\text { - sprawnych”; } \\
\text { - udział w Targach Sprzętu Rehabilitacyjnego; } \\
\text { - działania informacyjne z wykorzystaniem Internetu; } \\
\text { - promowanie aktywnych form spędzania czasu osób niepelnosprawnych. }\end{array}$ \\
\hline
\end{tabular}




\begin{tabular}{|c|c|}
\hline$[1]$ & [2] \\
\hline Efekty mierzalne & $\begin{array}{l}\text { - Informator z płytą CD Turystyka dla wszystkich - } 5000 \text { egz. } \\
\text { - Konferencja „Rola krajoznawstwa i turystyki w życiu osób niepełnosprawnych” - } 100 \text { osób. } \\
\text { - Wydawnictwo pokonferencyjne „Rola krajoznawstwa i turystyki w życiu osób niepełnosprawnych" - } 2000 \\
\text { egz. } \\
\text { - Strona internetowa www.turystykadlawszystkich.pl. } \\
\text { - Zweryfikowano ponad } 25000 \text { obiektów, z czego } 5000 \text { obiektów infrastruktury turystycznej spełniało wymogi } \\
\text { dostępności dla ON. } \\
\text { Dziéki realizacji projektu „Turystyka dla wszystkich” stwierdzono, że na terenie Polski istnieje } 5017 \text { obiektów, } \\
\text { które są dostępne dla osób z różnymi rodzajami niepełnosprawności. Bazę tę stanowi } 1578 \text { obiektów nocle- } \\
\text { gowych, } 1857 \text { lokali gastronomicznych, } 234 \text { biura podróży, } 126 \text { firm transportowych, } 825 \text { placówek kultural- } \\
\text { nych, } 234 \text { obiekty sportowe, } 106 \text { parków (narodowych, krajobrazowych, miejskich) oraz } 57 \text { szlaków tury- } \\
\text { stycznych. }\end{array}$ \\
\hline $\begin{array}{l}\text { Działania uzu- } \\
\text { pelniajace (semi- } \\
\text { naria, konkursy, } \\
\text { wystawy i inne) }\end{array}$ & $\begin{array}{l}\text { - Wystawa publikacji związanych z turystyką osób niepełnosprawnych. } \\
\text { - Konferencja prasowa z udziałem koordynatorów regionalnych i promocji efektów projektu. } \\
\text { - Warsztaty i rajd integracyjny (Nie)pełnosprawny turysta - podczas Międzynarodowych Targów Rehabilitacji. }\end{array}$ \\
\hline $\begin{array}{l}\text { Imprezy środo- } \\
\text { wiskowe i oddzia- } \\
\text { łowe }\end{array}$ & $\begin{array}{l}\text { Oddziały właczyły się do inwentaryzowania miejsc, ponadto działało w kraju } 16 \text { Komisji ds. Turystyki Osób } \\
\text { Niepełnosprawnych, a oddziały odnotowały uczestnictwo } 17547 \text { osób niepełnosprawnych w } 22413 \text { imprezach } \\
\text { turystyki kwalifikowanej (różnych form). }\end{array}$ \\
\hline Finansowanie & $\begin{array}{l}\text { Fundusz Inicjatyw Obywatelskich: 1) } 2006 \text { r. - środki przejściowe UE 2004-2006; 2) } 2008 \text { r. - budżet ZG PTTK. } \\
\text { Całkowite koszty kwalifikowane Projektu } 2008 \text { wynosily } 55 \text { 345,98 euro; kwota dotacji to } 49811,38 \text { euro, czyli } \\
90 \% \text { kosztów kwalifikowanych. }\end{array}$ \\
\hline \multicolumn{2}{|r|}{ Rok 2006} \\
\hline Akcja & Poznajemy ojczyznę (inicjatywa PTTK). \\
\hline Hasło/przesłanie & „Wędruj z nami”. \\
\hline Cel akcji & $\begin{array}{l}\text { Celem projektu było utrwalenie potrzeby pielęgnowania tożsamości narodowej i kulturowej poprzez promocję } \\
\text { rodzimej tradycji, popularyzowanie i upowszechnianie wiedzy o dziedzictwie narodowym poprzez Kanon Krajo- } \\
\text { znawczy Polski. }\end{array}$ \\
\hline Adresat & $\begin{array}{l}\text { Nauczyciele regionaliści, opiekunowie szkolnych kół turystyczno-krajoznawczych, dzieci i młodzież z całego } \\
\text { kraju. }\end{array}$ \\
\hline Zasięg & $\begin{array}{l}\text { Kanon na CD trafił poprzez Kuratoria Oświaty do } 25101 \text { szkół, } 349 \text { oddziałów PTTK, } 100 \text { schronisk młodzieżo- } \\
\text { wych PTSM, } 300 \text { drużyn harcerskich, } 2775 \text { SKT-K. }\end{array}$ \\
\hline $\begin{array}{l}\text { Imprezy/działania/ } \\
\text { konferencje/ publi- } \\
\text { kacje centralne }\end{array}$ & $\begin{array}{l}\text { W ramach projektu opracowano Kanon Krajoznawczy Polski, w którym znalazło się } 600 \text { obiektów krajoznaw- } \\
\text { czych w podziale na województwa. }\end{array}$ \\
\hline Efekty mierzalne & $\begin{array}{l}\text { Rezultatem stałym projektu było wydanie Kanonu Krajoznawczego Polski na CD w nakładzie } 30000 \text { oraz za- } \\
\text { mieszczenie go na stronie internetowej http://kanon.pttk.pl. }\end{array}$ \\
\hline $\begin{array}{l}\text { Działania uzu- } \\
\text { pełniające (semi- } \\
\text { naria, konkursy, } \\
\text { wystawy i inne) }\end{array}$ & $\begin{array}{l}\text { Promocja Kanonu na regionalnych spotkaniach z nauczycielami we współpracy z Kuratoriami Oświaty. } \\
\text { Informacja ukazała się też na stronach KO, które bardzo aktywnie włączyły się do promocji regionalizmu po- } \\
\text { przez dostęp do zawartości kanonu. }\end{array}$ \\
\hline $\begin{array}{l}\text { Imprezy środo- } \\
\text { wiskowe i oddzia- } \\
\text { łowe }\end{array}$ & Poprzez Regionalne Pracownie Krajoznawcze - lekcje regionalizmu. \\
\hline Finansowanie & Fundusz Inicjatyw Obywatelskich, budżet ZG PTTK. \\
\hline \multicolumn{2}{|r|}{ Rok 2007} \\
\hline Akcja & $\begin{array}{l}\text { Rok szlaków turystycznych (120 lat od wytyczenia pierwszego szlaku na ziemiach polskich - uchwała XVI Wal- } \\
\text { nego Zjazdu PTTK). }\end{array}$ \\
\hline Hasło/przesłanie & „Zanim wyruszysz na szlak” oraz „Wędruj z nami - szlaki czekaja”. \\
\hline Cel akcji & $\begin{array}{l}\text { Celem projektu było podniesienie poziomu wiedzy i świadomości społeczeństwa polskiego w obszarach } \\
\text { związanych z bezpiecznym korzystaniem ze szlaków turystycznych. }\end{array}$ \\
\hline Adresat & $\begin{array}{l}\text { Użytkownicy szlaków turystycznych - turyści (od młodzieży szkolnej do osób starszych), a także gestorzy } \\
\text { znakowanych szlaków turystycznych na terenie kraju. }\end{array}$ \\
\hline Zasięg & 150 miast z 16 województw, 2263 szkoły. \\
\hline
\end{tabular}

\section{8 | WARSZTATY Z GEOGRAFII TURYZMU}




\begin{tabular}{|c|c|}
\hline$[1]$ & [2] \\
\hline $\begin{array}{l}\text { Imprezy/działania/ } \\
\text { konferencje/ publi- } \\
\text { kacje centralne }\end{array}$ & $\begin{array}{l}\text { - Przeprowadzenie programu aktywnej edukacji ekologicznej i prozdrowotnej. } \\
\text { - Wsparcie akcji edukacyjnej wydawnictwami i publikacjami. } \\
\text { - Prowadzenie kampanii informacyjno-promocyjnej. } \\
\text { - Zorganizowanie konferencji popularnonaukowej. } \\
\text { - Działania informacyjne z wykorzystaniem Internetu. } \\
\text { - Promowanie aktywnych form spędzania czasu, ochrona zdrowia. } \\
\text { - Działania zwiazane ze znakowaniem szlaków turystycznych. }\end{array}$ \\
\hline Efekty mierzalne & $\begin{array}{l}\text { - Akcja „Zanim wyruszysz na szlak” - propagowanie bezpiecznego wędrowania - } 17014 \text { osób. } \\
\text { - Akcja „Wędruj z nami-szlaki czekaja” - } 45389 \text { osób. } \\
\text { - Międzynarodowa konferencja: „Szlaki turystyczne a przestrzeń turystyczna” - } 90 \text { osób. } \\
\text { - Foldery Znakowane szlaki turystyczne - } 8000 \text { egz. } \\
\text { - Plakaty „Rok szlaków” -10 } 000 \text { egz. } \\
\text { - Plakaty ostrzegawcze - } 2 \text { rodzaje po } 5000 \text { egz. } \\
\text { - Vademecum „ABC wędrowania”. } \\
\text { - Mapa Polska. Znakowane szlaki turystyczne - } 5000 \text { egz. } \\
\text { - Znaczki (50 } 000 \text { szt.). } \\
\text { - Certyfikaty (50 } 000 \text { szt.). } \\
\text { - CD „Wędruj z nami” - } 5000 \text { egz. } \\
\text { - Wydawnictwo pokonferencyjne - } 2000 \text { egz. }\end{array}$ \\
\hline $\begin{array}{l}\text { Działania uzu- } \\
\text { pełniające (semi- } \\
\text { naria, konkursy, } \\
\text { wystawy i inne) }\end{array}$ & $\begin{array}{l}\text { - Historia szlaków - Komisja Turystyki Pieszej ZG PTTK. } \\
\text { - Apel do Członków i Sympatyków PTTK Rady TON. } \\
\text { - "Zaprośmy osoby niepełnosprawne na ojczyste szlaki”. } \\
\text { - "Krasomówcze szlaki Podlasia - wspomnienie z warsztatów krasomówczych z } 16 \text { kwietnia } 2007 \text { r. } \\
\text { - "Tworzenie i promocja zintegrowanego systemu szlaków pogranicza Polski i Białorusi”. } \\
\text { - Galeria fotograficzna - COTG. }\end{array}$ \\
\hline $\begin{array}{l}\text { Imprezy środo- } \\
\text { wiskowe i oddzia- } \\
\text { lowe }\end{array}$ & $\begin{array}{l}\text { W ramach akcji uporzadkowano miejscowe szlaki, wspólnie z samorządami podejmowano inicjatywy odnowie- } \\
\text { nia, ale i likwidacji niektórych szlaków. } \\
\text { Ważnym elementem była edukacja w środowiskach szkolnych: „Zanim wyruszysz na szlak - jak się przygoto- } \\
\text { wać, z kim iść, co ze soba zabrać”. }\end{array}$ \\
\hline Finansowanie & Środki przejściowe UE - 52000 euro; budżet ZG PTTK. \\
\hline \multicolumn{2}{|r|}{ Rok 2007} \\
\hline Akcja & Edukacja ekologiczna na szlakach turystycznych (inicjatywa PTTK). \\
\hline Hasło/przesłanie & - \\
\hline Cel akcji & $\begin{array}{l}\text { Włączenie się w obchody Roku Szlaków Turystycznych poprzez: } \\
\text { - utworzenie strony internetowej www.edueko.pttk.pl; } \\
\text { - zinwentaryzowanie szlaków oddziałów, wprowadzenie do bazy danych; } \\
\text { - promocja edukacji ekologicznej na szlakach turystycznych PTTK. }\end{array}$ \\
\hline Adresat & Internauci - użytkownicy szlaków turystycznych. \\
\hline Zasięg & Ogólnopolska. \\
\hline $\begin{array}{l}\text { Imprezy/działania/ } \\
\text { konferencje/ publi- } \\
\text { kacje centralne }\end{array}$ & $\begin{array}{l}\text { Głównym zamierzeniem było zinwentaryzowanie zasobów szlaków w Polsce i zamieszczenie ich na stronie } \\
\text { internetowej www.edueko.pttk.pl, gdzie nie tylko szlaki, a także wiele informacji o ochronie przyrody znajdują się } \\
\text { w jednym miejscu. }\end{array}$ \\
\hline Efekty mierzalne & $\begin{array}{l}\text { Efekty rzeczowe: } \\
\text { - plakat „Edueko” (5000 egz.); } \\
\text { - strona internetowa poświęcona ekologii i przyrodzie - www.edueko.pttk.pl; } \\
\text { - szkolenie e-lerningowe (5000 egz.); } \\
\text { - baza e-mailowa (ponad } 5000 \text { szkół). } \\
\text { Efekty promocyjne: } \\
\text { - materiały dydaktyczne dla opiekunów SKKT, dla nauczycieli zainteresowanych turystyką i PTTK; } \\
\text { - zebrano w jednym miesiącu informacje o różnych rodzajach szlaków, w tym oddziałowych; } \\
\text { - możliwość przygotowania ciekawej wędrówki. }\end{array}$ \\
\hline $\begin{array}{l}\text { Działania uzu- } \\
\text { pełniajace (semi- } \\
\text { naria, konkursy, } \\
\text { wystawy i inne) }\end{array}$ & $\begin{array}{l}\text { Strona www.edueko.pttk.pl - ponad } 65000 \text { km szlaków, informacja o } 23 \text { parkach narodowych, } 131 \text { krajobra- } \\
\text { zowych, a także o pomnikach przyrody i innych ciekawostkach przyrodniczych. } \\
\text { E-lerning o możliwości planowania edukacji ekologicznej w oparciu o utworzoną stronę i jej zasoby (do ponad } \\
5000 \text { szkół). }\end{array}$ \\
\hline
\end{tabular}




\begin{tabular}{|c|c|}
\hline$[1]$ & {$[2]$} \\
\hline $\begin{array}{l}\text { Imprezy środo- } \\
\text { wiskowe i oddzia- } \\
\text { łowe }\end{array}$ & Oddziały nadsyłały informacje - opisy szlaków turystycznych znajdujących się w ich polu działania. \\
\hline Finansowanie & NFOŚiGW, budżet ZG PTTK. \\
\hline \multicolumn{2}{|r|}{ Rok 2007} \\
\hline Akcja & Edukacja ekologiczna kadry programowej PTTK - Natura 2000 (inicjatywa PTTK). \\
\hline Hasło/przesłanie & PTTK wobec obszarów Natura 2000. \\
\hline Cel akcji & $\begin{array}{l}\text { Doszkalanie kadry PTTK - przewodników, opiekunów SKKT ( pięć województw), działaczy RPK. } \\
\text { Wydanie płyty CD. }\end{array}$ \\
\hline Adresat & $\begin{array}{l}\text { Przewodnicy, opiekunowie SKKT, krajoznawcy skupieni przy Regionalnych Pracowniach Krajoznawczych } \\
\text { PTTK. }\end{array}$ \\
\hline Zasięg & Cztery oddziały, trzy województwa: mazowieckie, podlaskie, śląskie. \\
\hline $\begin{array}{l}\text { Imprezy/działania/ } \\
\text { konferencje/ publi- } \\
\text { kacje centralne }\end{array}$ & $\begin{array}{l}\text { Cykl warsztatów szkoleniowych poszerzających wiedzę zainteresowanych z zakresu obszarów zakwalifikowa- } \\
\text { nych do projektu Natura } 2000 .\end{array}$ \\
\hline Efekty mierzalne & Akcja regionalna - dotyczyła trzech województw. \\
\hline $\begin{array}{l}\text { Działania uzu- } \\
\text { pełniajace (semi- } \\
\text { naria, konkursy, } \\
\text { wystawy i inne) }\end{array}$ & $\begin{array}{l}\text { Powstała płyta CD z obszarami Natura } 2000 \text { zlokalizowanych na terenie województw: mazowieckiego, podlas- } \\
\text { kiego, śląskiego, która była rozpowszechniona wśród wszystkich oddziałów PTTK w Polsce. }\end{array}$ \\
\hline $\begin{array}{l}\text { Imprezy środo- } \\
\text { wiskowe i oddzia- } \\
\text { łowe }\end{array}$ & $\begin{array}{l}\text { Regionalne Pracownie Krajoznawcze prowadziły warsztaty dla zainteresowanych szkół w zakresie ochrony } \\
\text { przyrody na obszarach Natura } 2000 .\end{array}$ \\
\hline Finansowanie & NFOŚiGW, budżet ZG PTTK. \\
\hline \multicolumn{2}{|r|}{ Rok 2008} \\
\hline Akcja & Rok przyrody (inicjatywa PTTK - 100 lat od powstania Komisji Osobliwości Przyrody). \\
\hline Hasło/przesłanie & „Przyroda uczy najpiękniej”. \\
\hline Cel akcji & $\begin{array}{l}\text { Celem projektu było podniesienie poziomu wiedzy i świadomości społeczności lokalnych na obszarach zwiaza- } \\
\text { nych z ochrona dziedzictwa naturalnego, zwrócenie uwagi społeczeństwa na potrzebé zachowania zrównowa- } \\
\text { żonego środowiska, ze szczególnym nakierowaniem na obszary chronione, w tym sieć Natura 2000. Dażác do } \\
\text { zminimalizowania negatywnych skutków niewłaściwych zachowań turystów i osób korzystających ze środowiska } \\
\text { przyrodniczego PTTK chce podjać działania w celu kształtowania ich postaw przyjaznych środowisku wynikaja- } \\
\text { cych przede wszystkim z głębokiej wiedzy, świadomości i emocjonalnego zaangażowania. }\end{array}$ \\
\hline Adresat & $\begin{array}{l}\text { Nauczyciele - opiekunowie SKKT, osoby zainteresowane ochroną przyrody, organizacje pozarządowe, } \\
\text { uczelnie. }\end{array}$ \\
\hline Zasięg & Ogólnopolski - 16 województw, 1405 środowisk. \\
\hline $\begin{array}{l}\text { Imprezy/działania/ } \\
\text { konferencje/ publi- } \\
\text { kacje centralne }\end{array}$ & $\begin{array}{l}\text { Akcja „Czyste lasy, czyste wody, czyste góry”;akcja „Na tropie przyrody”. } \\
\text { Konferencja popularnonaukowa „Turystyka zrównoważona i ekoturystyka”. }\end{array}$ \\
\hline Efekty mierzalne & $\begin{array}{l}\text { - Akcja „Czyste lasy, czyste wody, czyste góry” - } 177 \text { miast, } 793 \text { szkoły i } 28376 \text { osób. } \\
\text { - Akcja „Na tropie przyrody” odznakę „Turysta Przyrodnik” zdobyło } 3000 \text { osób. } \\
\text { - Konferencja popularnonaukowa pt. „Turystyka zrównoważona i ekoturystyka” - } 27 \text { referatów, } 100 \text { osób. } \\
\text { - Folder Przyroda uczy najpiękniej - } 8000 \text { egz. } \\
\text { - Plakaty: dwa rodzaje nt. „Zdobywaj odznakę «Turysta Przyrodnik»” - } 10000 \text { egz. } \\
\text { - Konkursy: literacki - „Przyroda jak księga”, plastyczny - „Przyroda malowana” i fotograficzny - „Przyroda } \\
\text { wokół nas” - ok. } 6000 \text { prac. } \\
\text { - Ksiażzeczka Turysta przyrodnik - } 15000 \text { egz. } \\
\text { - Odznaka popularna „Turysta Przyrodnik” - } 3000 \text { szt. } \\
\text { - Wydawnictwo pokonferencyjne: Turystyka zrównoważona i ekoturystyka- } 2000 \text { egz. } \\
\text { - Szkolenie e-lerningowe „Przyroda uczy najpiękniej” (na płycie CD) - } 10000 . \\
\text { - Vademecum „Zostań turystą przyrodnikiem” - } 5000 \text { egz. }\end{array}$ \\
\hline $\begin{array}{l}\text { Działania uzu- } \\
\text { pełniajace (semi- } \\
\text { naria, konkursy, } \\
\text { wystawy i inne) } \\
\end{array}$ & $\begin{array}{l}\text { - Konferencja inaugurująca projekt - siedziba PTTK. } \\
\text { - Konkursy: literacki - „Przyroda jak księga”, plastyczny - „Przyroda malowana” i fotograficzny - „Przyroda } \\
\text { wokół nas”. } \\
\text { - Wystawa prac laureatów - galeria PTTK. }\end{array}$ \\
\hline
\end{tabular}

160 Warsztaty z GEOGRAFII TURYZMU 


\begin{tabular}{|c|c|}
\hline [1] & {$[2]$} \\
\hline $\begin{array}{l}\text { Imprezy środowis- } \\
\text { kowe i oddziałowe }\end{array}$ & $\begin{array}{l}\text { Kontynuacja akcji „Czyste góry” - Ustrzyki Górne, a także „Czysta woda” - Centrum Turystyki Wodnej i oddziały } \\
\text { żeglarskie PTTK. }\end{array}$ \\
\hline Finansowanie & Program Operacyjny Fundusz Inicjatyw Obywatelskich. Budżet ZG PTTK. \\
\hline \multicolumn{2}{|r|}{ Rok 2009} \\
\hline Akcja & $\begin{array}{l}\text { Rok dzieci i młodzieży (inicjatywa PTTK - } 90 \text { lat zorganizowanej turystyki w szkole). } \\
\text { Akcja „Przyroda uczy najpiękniej - II” (od IX } 2008 \text { do X } 2009 \text { r.). }\end{array}$ \\
\hline Hasło/przesłanie & „Przyroda uczy najpiękniej - II”. \\
\hline Cel akcji & $\begin{array}{l}\text { Realizując projekt w oparciu o aktywne formy edukacji, pragniemy zaangażować społeczności lokalne, co po- } \\
\text { zwoli zrealizować cele szczegółowe, jakimi sa: podniesienie świadomości społecznej na obszarach zwiazanych } \\
\text { ze środowiskiem oraz wypracowanie odpowiedzialnych i aktywnych postaw społeczeństwa w celu ochrony } \\
\text { naszego naturalnego dziedzictwa. }\end{array}$ \\
\hline Adresat & $\begin{array}{l}\text { W zależności komponentów realizowanych w ramach projektu, adresatami byli: } \\
\text { - społeczności lokalne; } \\
\text { - grupy młodzieżowe z terenu całego kraju; } \\
\text { - nauczyciele przewodnicy - kierownicy i organizatorzy wycieczek szkolnych; } \\
\text { - przewodnicy turystyczni obsługujący imprezy turystyczne; } \\
\text { - potencjalni twórcy produktu turystycznego w dziedzinie turystyki szkolnej i osób niepełnosprawnych po } \\
\text { parkach narodowych, parkach krajobrazowych i rezerwatach przyrody; } \\
\text { - przedstawiciele uczelni prowadzących kierunki: turystyka, ochrona środowiska, gospodarka przestrzenna. }\end{array}$ \\
\hline Zasięg & Ogólnopolski, ok. 1000 środowisk. \\
\hline $\begin{array}{l}\text { Imprezy/działania/ } \\
\text { konferencje/ publi- } \\
\text { kacje centralne }\end{array}$ & $\begin{array}{l}\text { - Uruchomiono serwis internetowy „Młodzież w PTTK” pod adresem www.mlodziez2009.pttk.pl. } \\
\text { - Ustanowiono Dziecięca Odznakę Turystyczna PTTK. } \\
\text { - Ogólnopolskie Forum Turystyki i Krajoznawstwa w Szkole; elementami forum były: Centralny Zlot Laureatów } \\
\text { XVI edycji Ogólnopolskiego Młodzieżowego Konkursu Krajoznawczego „Poznajemy ojcowiznę” oraz sesja } \\
\text { popularnonaukowa pt. „Nieprzemijające wartości szkolnego ruchu krajoznawczo-turystycznego”. } \\
\text { - I Ogólnopolskie Forum Młodzieżowych Liderów Turystyki. } \\
\text { - W ramach projektu „Przyroda uczy najpiękniej” zorganizowano dwie akcje: „Czyste lasy, czyste wody, czyste } \\
\text { góry” oraz „Na tropie przyrody”. } \\
\text { - Zorganizowano konferencje „Metodyka oprowadzania wycieczek szkolnych i osób niepełnosprawnych po } \\
\text { obszarach chronionych”. }\end{array}$ \\
\hline Efekty mierzalne & $\begin{array}{l}\text { - I Ogólnopolskie Forum Młodzieżowych Liderów Turystyki (64 przedstawicieli z } 22 \text { oddziałów PTTK z całej } \\
\text { Polski). } \\
\text { - Akcja „Czyste lasy, czyste wody, czyste góry” - } 341 \text { szkół oraz } 906 \text { klas, } 180 \text { SKKT, } 319 \text { innych środowisk } \\
\text { (np. drużyny harcerskie, koła ekologiczne) - } 42744 \text { osoby. } \\
\text { - Akcja „Na tropie przyrody” - wzięło udział } 19428 \text { osób. } \\
\text { - Konkursy literacki, plastyczny i fotograficzny - } 3793 \text { osoby z } 822 \text { środowisk (szkoły, Domy Kultury, Kluby } \\
\text { Osiedlowe). } \\
\text { - Ksiazzeczka Turysta przyrodnik - } 15000 \text { szt. } \\
\text { - Odznaka „Turysta Przyrodnik” - } 3000 \text { szt. } \\
\text { - Plakaty edukacyjne „ZOostań turysta przyrodnikiem” - } 10000 \text { szt. } \\
\text { - Folder Przyroda uczy najpiękniej - } 8000 \text { szt. } \\
\text { - ABC Turysty przyrodnika. Vademecum - } 5000 \text { szt. } \\
\text { - Płyta CD „Wędruj z nami - edukacja dla zrównoważonego rozwoju” - } 10000 \text { szt. } \\
\text { - Poradnik metodyczno-szkoleniowy „Przyroda uczy najpiękniej” - } 2000 \text { szt. } \\
\text { - Liczba osób korzystajacych z internetowej bazy danych www.rokprzyrody.pttk.pl - } 286279 . \\
\text { - Liczba uczestników konferencji popularnonaukowej - } 100 \text { osób. } \\
\text { - Liczba uczestników konferencji podsumowujacej projekt - } 250 \text { osób. }\end{array}$ \\
\hline $\begin{array}{l}\text { Działania uzu- } \\
\text { pełniające (semi- } \\
\text { naria, konkursy, } \\
\text { wystawy i inne) }\end{array}$ & $\begin{array}{l}\text { Zrealizowane zostały ogólnopolskie konkursy: plastyczny, literacki, fotograficzny; zorganizowano je w ramach } \\
\text { kontynuacji projektu „Przyroda uczy najpiękniej” dofinansowanego ze środków NFOŚiGW. } \\
\text { Na konkurs literacki „Przyroda, ach to ty?” nadesłano } 143 \text { prace. W konkursie fotograficznym „Środowisko wokół } \\
\text { nas” uczestniczyło } 530 \text { osób, które nadesłały } 1243 \text { prace. W konkursie plastycznym „Kocham i szanuję } \\
\text { przyrodę” wzięły udział } 173 \text { środowiska, z których wpłynęło } 1569 \text { prac. }\end{array}$ \\
\hline $\begin{array}{l}\text { Imprezy środo- } \\
\text { wiskowe i oddzia- } \\
\text { łowe }\end{array}$ & $\begin{array}{l}\text { Do Zarządu Głównego PTTK wpłynęły informacje z } 33 \text { jednostek PTTK. Zadeklarowano w nich, oprócz tradycyj- } \\
\text { nych imprez organizowanych rokrocznie na terenie kraju, w roku } 2009 \text { pod hasłem „Roku Dzieci i Młodzieży” } \\
\text { zorganizowane zostało w sumie } 951 \text { przedsięwzięć, w których uczestniczyło } 61172 \text { osób. }\end{array}$ \\
\hline Finansowanie & MSiT, Budżet ZG PTTK, NFOŚiGW, MEN, Urząd Marszałkowski Województwa Wielkopolskiego. \\
\hline
\end{tabular}




\begin{tabular}{|c|c|}
\hline [1] & [2] \\
\hline \multicolumn{2}{|r|}{ Rok 2009} \\
\hline Akcja & Edukacja ekologiczna kadry programowej PTTK - Natura 2000 (inicjatywa PTTK). \\
\hline Hasło/przesłanie & „PTTK wobec obszarów Natura 2000" \\
\hline Cel akcji & Doszkalanie kadry PTTK - przewodników, opiekunów SKKT, działaczy RPK. Wydanie płyty CD. \\
\hline Adresat & $\begin{array}{l}\text { Przewodnicy, opiekunowie SKKT, działacze regionalnych Pracowni Krajoznawczych z siedmiu woje- } \\
\text { wództw. }\end{array}$ \\
\hline Zasięg & $\begin{array}{l}\text { Siedem oddziałów, siedem województw: warmińsko-mazurskie, świętokrzyskie, lubelskie, łódzkie, podkarpackie, } \\
\text { zachodniopomorskie i dolnośląskie. }\end{array}$ \\
\hline $\begin{array}{l}\text { Imprezy/działania/ } \\
\text { konferencje/ publi- } \\
\text { kacje centralne }\end{array}$ & $\begin{array}{l}\text { Przygotowano formę czynnych warsztatów ekologicznych, która obejmowała aktywne zajęcia stacjonarne i wy- } \\
\text { cieczki krajoznawcze zmierzające do poszerzenia i utrwalenia wśród adresatów zadania praktycznej wiedzy } \\
\text { o ochronie przyrody na obszarach Natura } 2000 \text {. }\end{array}$ \\
\hline Efekty mierzalne & - \\
\hline $\begin{array}{l}\text { Działania uzu- } \\
\text { pełniające (semi- } \\
\text { naria, konkursy, } \\
\text { wystawy i inne) }\end{array}$ & - \\
\hline $\begin{array}{l}\text { Imprezy środo- } \\
\text { wiskowe i oddzia- } \\
\text { łowe }\end{array}$ & - \\
\hline Finansowanie & NFOŚiGW, budżet ZG PTTK. \\
\hline \multicolumn{2}{|r|}{ Rok 2010} \\
\hline Akcja & VI Kongres Krajoznawstwa Polskiego. \\
\hline Hasło/przesłanie & Polska w europejskiej rodzinie. Przenikanie kultur, idei i wartości. Powinności krajoznawców. \\
\hline Cel akcji & $\begin{array}{l}\text { Celem kongresu było ukazanie silnych tysiacletnich więzi naszego kraju z cywilizacją europejska, mimo rozma- } \\
\text { itych barier politycznych rozdzielających nasz kontynent, jak również stanowiło próbę określenia nowej sytuacji } \\
\text { krajoznawstwa w jednoczącej się Europie. }\end{array}$ \\
\hline Adresat & Osoby zainteresowane krajoznawstwem, praktycy i naukowcy. \\
\hline Zasięg & $\begin{array}{l}\text { Sejmiki przedkongresowe odbywały się na terenie całego kraju, a VI Kongres odbył się 10-12.09.2010 r. w OI- } \\
\text { sztynie. }\end{array}$ \\
\hline $\begin{array}{l}\text { Imprezy/działania/ } \\
\text { konferencje/ publi- } \\
\text { kacje centralne }\end{array}$ & $\begin{array}{l}\text { Uczestnicy Kongresu dokonali analizy aktualnej sytuacji polskiego krajoznawstwa w zmieniającej się sytuacji } \\
\text { kulturowej oraz wytyczyli główne kierunki działania Towarzystwa na najbliższe dziesięciolecie. Obrady Kongre- } \\
\text { su ukazały trwała tysiącletnią obecność naszego kraju i narodu w kulturze europejskiej. Świadomość europejska } \\
\text { to rozumienie polskiego wkładu w kształtowanie kultury kontynentu, rozumienie wspólnoty dziejów i dojrzały } \\
\text { wybór form koegzystencji. Poznanie dziejów ziemi ojczystej uświadamia fakt wspólnego trwania z narodami } \\
\text { Europy Środkowej, jest zarazem lekcją wzajemnego szacunku i tolerancji. }\end{array}$ \\
\hline Efekty mierzalne & $\begin{array}{l}\text { Obrady Kongresu odbywały się w czterech zespołach tematycznych: „Przemiany krajobrazu kulturowego } \\
\text { w Polsce. Tradycja, współczesność, przyszłość”, „Krajoznawstwo w społeczeństwie wiedzy”, Krajoznawstwo } \\
\text { wobec wyzwań integrujacej się Europy”, „Asymilacja i współistnienie kultur na przestrzeni dziejów } \\
\text { w Polsce”. }\end{array}$ \\
\hline $\begin{array}{l}\text { Działania uzu- } \\
\text { pelniające (semi- } \\
\text { naria, konkursy, } \\
\text { wystawy i inne) }\end{array}$ & $\begin{array}{l}\text { - W Kongresie wzięło udział } 600 \text { osób. } \\
\text { - Wydano VI zeszytów naukowych, dwa „Kanony krajoznawcze województw: wielkopolskiego i warmińsko-ma- } \\
\text { zurskiego”, specjalne wydanie periodyku „Ziemia w Swoje Stulecie”. } \\
\text { - Wystawy przygotowane przez Urzad Wojewódzki Warmińsko-Mazurski, Starostwo w Ostródzie oraz PTTK: } \\
150 \text { lat Kanału Elblaskiego - Makieta Pochylni Oleśnica, Warmia - Ziemia Kopernika, Mazury - Cud Natury, } \\
\text { Dzieje Kongresów Krajoznawstwa Polskiego „Ziemia 1910-2010” - sto lat w służbie polskiego krajoznaw- } \\
\text { stwa, „Drogi poznania ojczyzny w odznakach krajoznawczych” - prace laureatów XVII edycji Ogólnopolskie- } \\
\text { go Młodzieżowego Konkursu Krajoznawczego „Poznajemy Ojcowiznę”. } \\
\text { - Impresje z Amorgos. }\end{array}$ \\
\hline $\begin{array}{l}\text { Imprezy środo- } \\
\text { wiskowe i oddzia- } \\
\text { łowe }\end{array}$ & $\begin{array}{l}\text { Zorganizowano } 24 \text { sejmiki popularnonaukowe na ternie całego kraju. Pierwszy odbył się już W } 2009 \text { r. pod } \\
\text { hasłem „Wzajemne przenikanie kultur w regionie łódzkim a nowe możliwości ruchu krajoznawczego”. Sejmi- } \\
\text { kowi towarzyszyło wydawnictwo zatytułowane tak jak brzmiało hasło sejmiku. Relacje znajdują się na stronie } \\
\text { www.vikongres.pttk.pl. }\end{array}$ \\
\hline Finansowanie & MSiT, Urząd Marszałkowski , Województwa Warmińsko-Mazurskiego, Bank Zachodni WBK (sponsor). \\
\hline
\end{tabular}

162 | WARSZTATY Z GEOGRAFII TURYZMU 


\begin{tabular}{|c|c|}
\hline [1] & [2] \\
\hline \multicolumn{2}{|r|}{ Rok 2010} \\
\hline Akcja & Rok wody (uchwała XVII Walnego Zjazdu PTTK). \\
\hline Hasło/przesłanie & „Bezpieczna woda”. \\
\hline Cel akcji & $\begin{array}{l}\text { Centrum Turystyki Wodnej PTTK razem z Komisjami Turystyki Kajakowej, Żeglarskiej i Działalności Podwodnej } \\
\text { ZZG PTTK oraz kołami, klubami i oddziałami PTTK są realizatorami uchwały XVII Walnego Zjazdu PTTK o usta- } \\
\text { nowieniu roku } 2010 \text { „Rokiem turystyki wodnej”. Przyjęto program zakładajacy aktywność struktur PTTK w dzie- } \\
\text { sięciu obszarach. Program realizowany był z uwzględnieniem akcji planowanych przez MSiT, które objęło } \\
\text { patronatem „Rok turystyki wodnej”, Polską Organizację Turystyczna, która ogłosiła konkurs na Najlepsze } \\
\text { Europejskie Destynacje Turystyczne EDEN - „Turystyka wodna”. }\end{array}$ \\
\hline Adresat & Turyści wodniacy, samorządy miejscowości zlokalizowanych nad woda. \\
\hline Zasięg & Cały kraj (brak szczegółowych raportów). \\
\hline $\begin{array}{l}\text { Imprezy/działania/ } \\
\text { konferencje/ publi- } \\
\text { kacje centralne }\end{array}$ & $\begin{array}{l}\text { 1. Konferencje. } \\
\text { 2. Spotkania warsztatowe: inwestycje i promocja turystyki wodnej - ogólna koncepcja i wstępny harmonogram } \\
\text { planowania strategicznego - wymiana doświadczeń. } \\
\text { 3. Targi: } \\
\text { - Sosnowiec: Międzynarodowe Targi Turystyki Rekreacji i Wypoczynku; } \\
\text { - Warszawa: Targi „Wiatr i Woda”; wręczenie nagrody Przyjaznego Brzegu za } 2009 \text { r.; wręczenie nagrody } \\
\text { specjalnej Prezesa ZG PTTK za najciekawszą ofertę targów adresowaną do osób niepełnosprawnych; } \\
\text { konferencja z udziałem laureatów i środowiska wodnego; } \\
\text { - Gdynia: Targi „Wiatr i Woda na Wodzie”; } \\
\text { - Poznań: Targi Boat Show. } \\
\text { 4. Realizacje medialne: } \\
\text { - Rejs Modlin-Zapora w Dębem (Zalew Zegrzyński); uczestnicy: dziennikarze zajmujący się problematyką } \\
\text { wodna; } \\
\text { - konferencja prasowa (czerwiec): Warszawa - Centrum Prasowe PAP (ul. Bracka); uczestnicy: dziennikarze } \\
\text { polscy i zagraniczni zajmujący się problematyką turystyki wodnej; współorganizator: Polska Organizacja } \\
\text { Turystyki; } \\
\text { - Artykuły w prasie branżowej nt. Roku turystyki wodnej. }\end{array}$ \\
\hline Efekty mierzalne & $\begin{array}{l}\text { Wydawnictwa: } \\
\text { - Są w Polsce przyjazne brzegi - przegląd osiagnięć laureatów nagrody „Przyjazny Brzeg” - praca zbior.; } \\
\text { - Poradnik dla dzieci - bezpieczeństwo na polskich szlakach wodnych; } \\
\text { - Polskie mosty widziane z polskich szlaków wodnych - turystyczny przegląd; } \\
\text { - „Polish Waterways” - wydawnictwo polsko-angielskie opisujące główne polskie szlaki wodne i akweny, } \\
\text { będące wprowadzeniem do przyszłego atlasu polskich dróg wodnych i szlaków wodnych; } \\
\text { - Polska nad Woda - założenia i elementy (książka). }\end{array}$ \\
\hline $\begin{array}{l}\text { Działania uzu- } \\
\text { pełniajace (semi- } \\
\text { naria, konkursy, } \\
\text { wystawy i inne) }\end{array}$ & 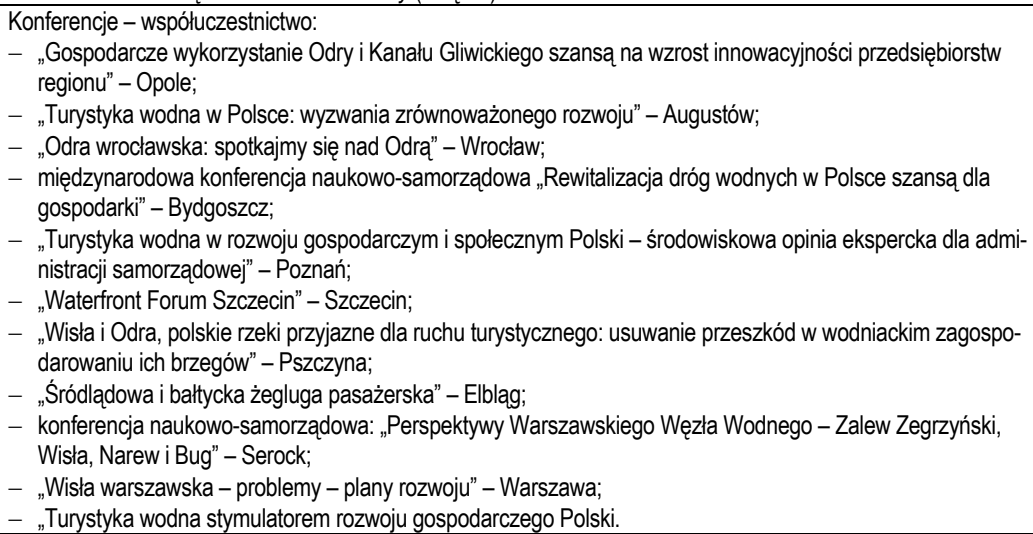 \\
\hline $\begin{array}{l}\text { Imprezy środo- } \\
\text { wiskowe i oddzia- } \\
\text { łowe }\end{array}$ & $\begin{array}{l}\text { Ogólnopolski Konkurs Plastyczny „Moje najmilsze chwile spędzone nad woda” - Komisja Środowiskowa ZG } \\
\text { PTTK. Udział w realizacji akcji informacyjno-edukacyjnej „Bezpieczna woda”: Ministerstwo Sportu i Turystyki, } \\
\text { Ministerstwo Edukacji Narodowej, MSWiA, POT, PTTK, WOPR, Komenda Główna Policji. }\end{array}$ \\
\hline Finansowanie & Budżet ZG PTTK, MSiT. \\
\hline
\end{tabular}




\begin{tabular}{|c|c|}
\hline [1] & [2] \\
\hline \multicolumn{2}{|r|}{ Rok 2011} \\
\hline Akcja & Tworzenie wzorców turystyki rodzinnej (inicjatywa PTTK). \\
\hline Hasło/przesłanie & „Rok turystyki rodzinnej”. \\
\hline Cel akcji & $\begin{array}{l}\text { Cele projektu: } \\
\text { - promocja spędzania czasu wolnego przez rodziny w sposób aktywny; } \\
\text { - zachęcenie rodzin do wspólnego systematycznego uprawiania turystyki i krajoznawstwa w różnych formach; } \\
\text { - kształtowanie prozdrowotnego stylu życia; } \\
\text { - popularyzacja krajoznawstwa i „Małych Ojczyzn”; } \\
\text { - kształtowanie zachowań proekologicznych, aby zachować teraźniejszość dla przyszłości. }\end{array}$ \\
\hline Adresat & $\begin{array}{l}\text { W ramach „Roku turystyki rodzinnej” w PTTK zainicjowano wiele działań zwiazzanych z turystyką rodzinną. Miały } \\
\text { one zarówno charakter praktyczny (np. realizowane konkursy), popularyzatorski (strona internetowa } \\
\text { www.rodzina.pttk.pl, publikacje) i naukowy (konferencja popularnonaukowa, publikacja pokonferencyjna). } \\
\text { Poprzez ich realizację przekonano się, że jest wiele rodzin, dla których zagospodarowanie czasu wolnego } \\
\text { poprzez wspólne wędrowanie, to ciekawe wyzwanie. }\end{array}$ \\
\hline Zasięg & $\begin{array}{l}\text { Zadanie adresowane zarówno do wielopokoleniowej rodziny, jak i organizatorów imprez dla rodzin, uczelni - } \\
119 \text { miejscowości w } 16 \text { województwach. }\end{array}$ \\
\hline $\begin{array}{l}\text { Imprezy/działania/ } \\
\text { konferencje/ publi- } \\
\text { kacje centralne }\end{array}$ & $\begin{array}{l}\text { 1. Ogólnopolski konkurs „Turystyczna Rodzinka”. } \\
\text { 2. Zdobywanie odznak turystyki kwalifikowanej, m.in. „Mama, tata, rower i ja”, „Turysta Senior”, „Dziecięca Od- } \\
\text { znaka Turystyczna” i inne. } \\
\text { 3. Publikacje: } \\
\text { - poradnik Rodzinne wędrowanie; } \\
\text { - płyta CD „Od dzidziusia do dziadziusia, czyli wędrować każdy może”; } \\
\text { - plakaty promujace turystykę rodzinna; } \\
\text { - konferencja popularnonaukowa pt. „Turystyka rodzinna a zachowania prospołeczne” z publikacja; } \\
\text { - strona interentowa www.rodzina.pttk.pl. }\end{array}$ \\
\hline Efekty mierzalne & $\begin{array}{l}\text { - Ogólnopolski konkurs „Turystyczna Rodzinka” - zgłosiło się } 226 \text { rodzin ( } 973 \text { osoby) ze } 119 \text { miejscowości } \\
\text { - (16 województw). } \\
\text { - Konferencja popularnonaukowa pt. „Turystyka rodzinna a zachowania prospołeczne” - } 100 \text { osób; z publika- } \\
\text { cja } 2000 \text { egz. } \\
\text { - Publikacje: Turystyka rodzinna a zachowania prospołeczne - } 2000 \text { egz.; poradnik Rodzinne wędrowanie. } \\
\text { Czyli jak wędrować z dzieckiem aby go nie zniechęcić do turystyki - } 15000 \text { egz. } \\
\text { - Szkolenie e-lerningowe „Od dzidziusia do dziadziusia, czyli wędrować każdy może” - } 10000 \text { tys. } \\
\text { - Płyta CD „Rodzinne wędrowanie” - } 10000 \text { tys. } \\
\text { - Konferencja podsumowująca - } 200 \text { osób. } \\
\text { - Wystawa prac plastycznych i fotograficznych. }\end{array}$ \\
\hline $\begin{array}{l}\text { Działania uzu- } \\
\text { pełniające (semi- } \\
\text { naria, konkursy, } \\
\text { wystawy i inne) }\end{array}$ & $\begin{array}{l}\text { Zorganizowano dwa konkursy uzupełniające: } \\
\text { 1) plastyczny - „Moja rodzina na turystycznym szlaku”; na konkurs wpłynęły } 264 \text { prace (I kat. - przedszkola: } \\
37 \text { prac, II kat. - SP: } 176 \text { prac, III kat. - gimnazja: } 51 \text { prac) z } 61 \text { środowisk; } \\
\text { 2) fotograficzny - „Nasze rodzinne wędrowanie”, na który wpłynęło ponad } 214 \text { prac } 52 \text { uczestników z } 16 \text { miej- } \\
\text { scowości. }\end{array}$ \\
\hline $\begin{array}{l}\text { Imprezy środo- } \\
\text { wiskowe i oddzia- } \\
\text { łowe }\end{array}$ & $\begin{array}{l}\text { Oddziały PTTK zorganizowały łącznie } 240 \text { imprez adresowanych do rodzin, w których wzięły udział } 31332 \text { oso- } \\
\text { by. }\end{array}$ \\
\hline Finansowanie & MSiT, budżet ZG PTTK. \\
\hline \multicolumn{2}{|r|}{ Rok 2012} \\
\hline Akcja & Rowerem przez Polskę (60 lat zorganizowanej turystyki rowerowej - inicjatywa PTTK). \\
\hline Hasło/przesłanie & „Rok turystyki rowerowej”. \\
\hline Cel akcji & $\begin{array}{l}\text { Celem projektu jest uświadomienie i zwrócenie uwagi na to, że rowerzyści są pełnoprawnymi uczestnikami } \\
\text { ruchu drogowego. Poprzez realizację zadania chcemy promować wśród rowerzystów bezpieczna jazdę, zgodną } \\
\text { z zasadami ruchu drogowego, jak również zdrowego rozsądku i wyobraźni, natomiast wśród kierowców pojaz- } \\
\text { dów chcemy zwrócić uwagę na uczestników ruchu drogowego, jakimi są rowerzyści. Kolejnym, bardzo istotnym } \\
\text { celem projektu jest podniesienie poziomu wiedzy i świadomości społeczeństwa związanej z bezpieczeństwem } \\
\text { turystyki rowerowej, ochroną dziedzictwa naturalnego i kulturowego, prozdrowotnej funkcji turystyki i krajoznaw- } \\
\text { stwa na etapie zagospodarowania czasu wolnego. }\end{array}$ \\
\hline
\end{tabular}

164 | WARSZTATY Z GEOGRAFII TURYZMU 


\begin{tabular}{|c|c|}
\hline [1] & [2] \\
\hline Adresat & $\begin{array}{l}\text { Zadanie akcji to kompleksowe działania PTTK ukierunkowane na bezpieczeństwo uprawiania turystyki } \\
\text { rowerowej, edukację dzieci, młodzież i ludzi młodych duchem, którzy zaliczają się do coraz liczniejszej grupy } \\
\text { Polaków zafascynowanych rowerem jako środkiem komunikacji. Rowery nie tylko daje dużą radość z szybkiego } \\
\text { przemieszczania się, ale także stanowi najzdrowszy i najbardziej ekologiczny sposób na poznawanie nie tylko } \\
\text { najbliższej okolicy zamieszkania, ale także Polski i Europy. }\end{array}$ \\
\hline Zasięg & $\begin{array}{l}\text { Zadanie akcji PTTK adresuje do wielopokoleniowego społeczeństwa zainteresowanego bezpiecznym uprawia- } \\
\text { niem turystyki rowerowej, a także do samorządów odpowiedzialnych za infrastrukturę rowerowa, służb drogo- } \\
\text { wych i innych stowarzyszeń i organizacji. }\end{array}$ \\
\hline $\begin{array}{l}\text { Imprezy/działania/ } \\
\text { konferencje/ publi- } \\
\text { kacje centralne }\end{array}$ & $\begin{array}{l}\text { W ramach projektu zorganizowano dwie ogólnopolskie akcje: 1) „Bezpiecznie na rowerze”, adresowana do } \\
\text { ogółu społeczeństwa, oraz 2) „Gmina przyjazna rowerzystom”, adresowana do jednostek samorządowych. } \\
\text { Promujemy poznawanie walorów turystyczno-krajoznawczych kraju poprzez zdobywanie Kolarskiej Odznaki } \\
\text { Turystycznej. Zostanie wydamy poradnik dla początkujących rowerzystów pt. Wybieram rower, a dla rodzin } \\
\text { przeprowadzimy warsztaty: „Mama, tata, rower i ja”. Ważnym elementem zadania będzie międzynarodowa } \\
\text { konferencja „Europejskie szlaki rowerowe” z udziałem przedstawicieli UECT (Union Europeenne de Cyclo- } \\
\text { tourisme - Europejski Zwiazzek Turystyki Rowerowej), której trwałym efektem będzie publikacja pokonferencyj- } \\
\text { na. Projekt zakończony będzie w połowie listopada konferencją podsumowująca wszystkie działania („Turystyka } \\
\text { rowerowa w zjednoczonej Europie”), wystawą prac laureatów i wręczeniem certyfikatów gminom przyjaznym } \\
\text { rowerzystom. }\end{array}$ \\
\hline Efekty mierzalne & $\begin{array}{l}\text { - Uczestnicy akcji „Bezpiecznie na rowerze” zgłosili się (do } 30.05 .2012 \text { r.) z } 79 \text { środowisk z } 70 \text { miejscowości, } \\
\text { planuje się } 369 \text { imprez dla } 24784 \text { osób. } \\
\text { - Osoby zainteresowane zdobywaniem Kolarskiej Odznaki Turystycznej reprezentują } 44 \text { środowiska z } 42 \\
\text { miast - } 5543 \text { osoby. } \\
\text { - Konkurs „Turystyczna Rodzinka” - zgłosiło się (do } 30.05 .2012 \text { r.) } 151 \text { rodzin - } 667 \text { osób z } 91 \text { miejscowości. } \\
\text { - Publikacje: Kalendarz imprez rowerowych ( } 5000 \text { egz.), Informator specjalny dla kolarzy (1000 egz.), poradnik } \\
\text { Wybieram rower ( } 5000 \text { egz.). } \\
\text { - Międzynarodowa konferencja nt. „Turystyka rowerowa w zjednoczonej Europie” - } 100 \text { osób. } \\
\text { - Publikacja konferencyjna pt. Turystyka rowerowa w zjednoczonej Europie”. }\end{array}$ \\
\hline $\begin{array}{l}\text { Działania uzu- } \\
\text { pełniające (semi- } \\
\text { naria, konkursy, } \\
\text { wystawy i inne) }\end{array}$ & Zorganizowano dwa ogólnopolskie konkursy: plastyczny i fotograficzny. \\
\hline $\begin{array}{l}\text { Imprezy środo- } \\
\text { wiskowe i oddzia- } \\
\text { łowe }\end{array}$ & Akcja trwa - meldunki będą zbierane dopiero na koniec listopada. \\
\hline Finansowanie & MSiT, budżet ZG PTTK. \\
\hline
\end{tabular}

Źródło: Opracowanie autorski na podstawie archiwów projektów (ZG PTTK).

PTTK od kilku lat z powodzeniem przygotowuje wnioski na konkursy ogłaszane przez Ministerstwo Sportu i Turystyki (MSiT) związane z realizacją różnorodnych zadań publicznych. W ostatnich latach MSiT pozytywnie oceniło wnioski i dofinansowało w:

- 2009 r. Rok Dzieci i Młodzieży;

- 2010 r. VI Kongres Krajoznawstwa Polskiego i Rod Turystyki Wodnej;

- 2011 r. Rok Turystyki Rodzinnej;

- 2012 r. Rok Turystyki Rowerowej.

Należałoby tutaj wspomnieć, że Towarzystwo każdego roku składa wiele wniosków na realizację zadań statutowych m.in. do NFOŚiGW, PO FIO, Państwowego Funduszu Rehabilitacji Osób Niepełnosprawnych (PF $\mathrm{RON})$, ale pomimo ich wysokiej oceny merytorycznej nie udaje się uzyskać 
dofinansowania. Powodem jest fakt, że organizacji jest coraz więcej, a środków na ich realizację coraz mniej.
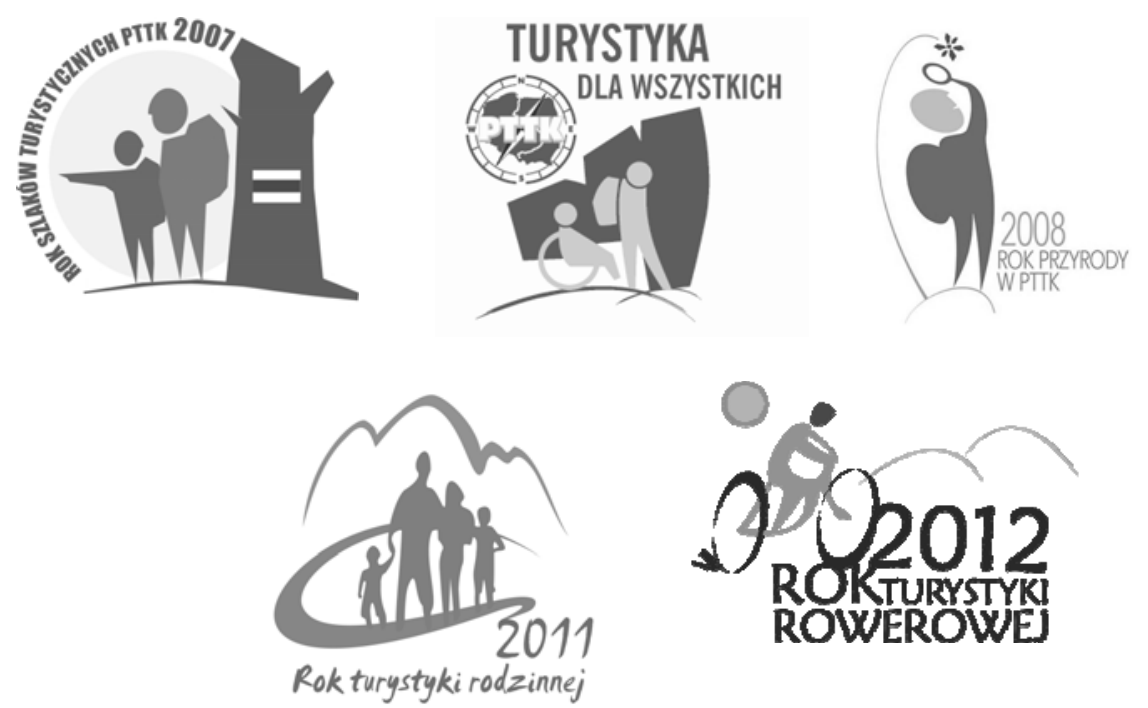

Rys. 1. Logo wybranych akcji realizowanych przez PTTK w latach 2007-2012 Źródło: archiwalia ZG PTTK

Akcje inicjowane przez Polskie Towarzystwo Turystyczno-Krajoznawcze zestawione $\mathrm{w}$ tab. 1 pokazują szerokie spektrum działalności Towarzystwa. Każde z przedsięwzięć (rys. 1) dotyczyło innej sfery działalności, miało inne cele, adresowane było do innej grupy społecznej, a wiele z nich pozostawiło trwały ślad $\mathrm{w}$ postaci publikacji czy funkcjonującej strony internetowej. Ważne rocznice związane z działalnością PTTK stają się też motywem przewodnim akcji, które są realizowane w kolejnych latach, np.:

- rok 2007 to 120 lat od wytyczenia pierwszego szlaku w Polsce - Rok Szlaków Turystycznych i wiele działań nie tylko popularyzatorskich, takich jak akcje „Zanim wyruszysz na szlak” czy „Wędruj z nami”, ale zorganizowano międzynarodową konferencję popularnonaukową "Szlaki turystyczne a przestrzeń turystyczna";

- rok 2008 podkreślił działania nakierowane na ochronę przyrody (inicjatywa Komisji Ochrony Przyrody działającej przy Zarządzie Głównym PTTK w 100 rocznicę od momentu powstanie Komisji Ochrony Osobliwości Przyrody); 
- $\quad$ w roku 2009 Rada ds. Turystyki Szkolnej Dzieci i Młodzieży ZG PTTK zainicjowała obchody Roku Dzieci i Młodzieży, podkreślając przypadającą 90. rocznicę zorganizowanej turystyki w szkole;

- w roku 2012 inicjatywy Komisji Turystyki Kolarskiej ZG PTTK w 60-lecie powstania komisji i zainicjowania cyklu imprez rowerowych o charakterze turystycznym - Zarząd Główny PTTK ustanowił ten rok Rokiem Turystyki Rowerowej.

\section{Promocja akcji, czyli budowanie wizerunku PTTK}

Zasadniczą sprawą w promocji jest określenie celów, priorytetów i metod jej realizacji. Cele zmierzają do przedstawienia Polskiego Towarzystwa Turystyczno-Krajoznawczego jako:

- stowarzyszenia turystów samodzielnie organizujących turystykę dla siebie i dla innych;

- głównego animatora turystyki aktywnej w Polsce;

- organizacji skupiającej doświadczoną kadrę turystyczno-krajoznawczą;

- gestora ogólnodostępnej i zróżnicowanej bazy turystycznej;

- organizatora „turystyki patriotycznej” $\mathrm{z}$ bogatym programem krajoznawczym.

Najważniejszym zadaniem w poszczególnych latach było podporządkowanie wszystkich działań promocyjnych Towarzystwa głównym wydarzeniom - akcjom zaplanowanym $\mathrm{w}$ danym roku. Wiele przedsięwzięć przewidywało dla uczestników znaczki okolicznościowe i certyfikaty uczestnictwa (Międzynarodowy Rok Gór, Spotkanie u Źródeł Rzek, Sadzimy Las, Rok Szlaków Turystycznych, Turystyczna Rodzinka). Każdy projekt miał przygotowaną oprawę graficzna, w tym zaprojektowane logo i plakat promujące główną myśl - ideę projektu. Od kilku lat akcje promowane są na targach turystycznych w kraju, na stoisku PTTK, gdzie wystrój stoiska sygnalizuje, jakie działania $\mathrm{w}$ danym roku sa priorytetowe dla Towarzystwa. Na podkreślenie zasługuje fakt, że poradniki, publikacje, materiały szkoleniowe i płyty CD wydawane $w$ ramach projektów są nieodpłatnie udostępnione na stoisku PTTK wszystkim zainteresowanym tematem czy wybraną dziedziną turystyki. Akcje zaczynają się i kończą konferencjami dla mediów i zainteresowanych instytucji. Bierze w nich udział od 40 do 250 osób. Wspomnieć należy jeszcze o trwałym efekcie projektów - powstających stronach internetowych, które są uzupełnieniem działań pozwalającym zaprezentować 
realizowane projekty $\mathrm{w}$ znacznie szerszym zakresie niż $\mathrm{np}$. $\mathrm{w}$ wydawnictwach drukowanych. Zamieszczane są na nich prace konkursowe, przykłady dobrych praktyk, które jednocześnie traktowane są jako działania ewaluacyjne. Publikacje, szkolenia e-learningowe, materiały popularyzatorskie, które powstają $\mathrm{w}$ ramach konkretnej akcji są zamieszczane na stronach internetowych po to, aby mogły z nich skorzystać kolejne osoby zainteresowane.

\section{Zasięg oddziaływania akcji}

Działania podejmowane przez PTTK $\mathrm{w}$ ramach realizowanych akcji (projektów) kierowane do ogółu społeczeństwa (tab. 2, rys. 2.) zyskują duże zainteresowanie różnych środowisk na terenie całego kraju. Na przykładzie akcji Rok Szlaków Turystycznych, jednej z pierwszych akcji zrealizowanej przez PTTK ze środków przejściowych Unii Europejskiej ${ }^{9}$, w której wzięło udział prawie 70000 osób, został pokazany zasięg jej oddziaływania w układzie wojewódzkim (tab. 3, rys. 3). Celem projektu było podniesienie poziomu wiedzy i świadomości społeczeństwa polskiego nt. bezpiecznego korzystania ze szlaków turystycznych. Realizacja projektu wynikała z rozpoznanego wcześniej braku znajomości wśród turystów zasad korzystania ze szlaków oraz odpowiednich działań $\mathrm{w}$ tym zakresie adresowanych do tej grupy. Kampania prowadzona była w 16 województwach i skierowana została do Wojewódzkich Porozumień Oddziałów PTTK ${ }^{10}$. Do projektu zgłosiło się 88 oddziałów PTTK, które zaplanowały uczestnictwo w nich 65586 osób z 1852 środowisk (szkoły, koła, kluby, zakłady pracy i inne). Na ogólną liczbę 329 oddziałów działających w Polsce w projekcie wzięło udział $88 \mathrm{z}$ nich, co stanowi 26,7\% ogólnej ich liczby. Największa liczba oddziałów reprezentowała województwa: łódzkie (11), dolnośląskie i mazowieckie (po 10) oraz lu-

\footnotetext{
9 Projekt złożony do Instytucji Finansującej - Fundacja „Fundusz Współpracy” w ramach środków przejściowych na lata 2004-2006 na kwotę 52854,11 Euro(wg przeliczenia kursu euro = 208 165,91; z tego dofinansowano 90\%, czyli 42 283,29 euro = $165532,73 \mathrm{zł}$ - pozostała kwota pochodziła z budżetu Zarządu Głównego PTTK).

10 Oddziały mogą tworzyć jednostki regionalne z osobowością prawną lub bez osobowości prawnej. Do zadań jednostek regionalnych tworzonych przez oddziały, mających swoją siedzibę na terenie tego samego województwa, należą w szczególności: reprezentacja PTTK wobec wojewódzkich władz rządowych i samorządowych, urzędów, instytucji i organizacji w granicach udzielonych pełnomocnictw, inspirowanie, inicjowanie i wspomaganie działalności programowej i gospodarczej oddziałów oraz podejmowanie wspólnych przedsięwzięć, integracja i koordynacja działalności oddziałów, udzielenie pomocy oddziałom w realizacji ich zadań statutowych, podejmowanie innych zadań zleconych przez Zarząd Główny lub oddziały (Statut PTTK, 2006, art. 78, s. 35).
} 
buskie (siedem). Najmniej podlaskie (dwa) oraz podkarpackie i pomorskie (po trzy) (tab. 2, rys. 2). Pod względem liczby zgłoszonych uczestników przodowały województwa: dolnośląskie, mazowieckie, małopolskie i śląskie, a najmniejszą liczbę uczestników zanotowano z terenów województw warmińsko-mazurskiego, podlaskiego, pomorskiego i lubuskiego. Największą liczbę środowisk zaangażowanych $\mathrm{w}$ realizowany projekt wykazały województwa: łódzkie (śląskie, mazowieckie i świętokrzyskie, najmniej było ich w województwie podlaskim, kujawsko-pomorskim, lubuskim i lubelskim. Pod względem zmobilizowania największej liczby uczestników przez oddziały (licząc średnią przypadającą na jeden oddział zgłoszony z województwa) najlepiej wypadły województwa: zachodniopomorskie (2379 osoby/ oddział), świętokrzyskie (1477 osób/oddział) i małopolskie (1183 osoby/ oddział). Najsłabiej pod tym względem wypadły województwa: lubuskie (228 osób/oddział), podlaskie (298 osób/oddział) i pomorskie (320 osób/ oddział). Średnio w Polsce jeden oddział zgłoszony do udziału w projekcie reprezentowało 745 osób.

Tabela 2. Udział Wojewódzkich Porozumień Oddziałów PTTK w projekcie Rok Szlaków Turystycznych

\begin{tabular}{|l|c|c|c|}
\hline \multirow{2}{*}{$\begin{array}{c}\text { Porozumienie Oddziałów } \\
\text { PTTK Województwa }\end{array}$} & \multicolumn{3}{|c|}{ Zgłoszona liczba } \\
\cline { 2 - 4 } & oddziałów PTTK & uczestników & $\begin{array}{c}\text { środowisk } \\
\text { (szkoły, kluby, koła) }\end{array}$ \\
\hline Dolnośląskiego & 10 & 8861 & 95 \\
\hline Kujawsko-pomorskiego & 4 & 4310 & 29 \\
\hline Lubelskiego & 5 & 4092 & 79 \\
\hline Lubuskiego & 7 & 1598 & 48 \\
\hline Łódzkiego & 11 & 6945 & 303 \\
\hline Małopolskiego & 6 & 7100 & 166 \\
\hline Mazowieckiego & 10 & 7180 & 192 \\
\hline Opolskiego & 6 & 2319 & 84 \\
\hline Podkarpackiego & 3 & 2319 & 97 \\
\hline Podlaskiego & 2 & 597 & 53 \\
\hline Pomorskiego & 3 & 962 & 206 \\
\hline Śląskiego & 6 & 6120 & 126 \\
\hline Świętokrzyskiego & 4 & 5910 & 10 \\
\hline Warmińsko-mazurskiego & 1 & 470 & 84 \\
\hline Wielkopolskiego & 7 & 4364 & 1852 \\
\hline Zachodniopomorskiego & 2 & 4758 & 65586 \\
\hline Razem & 88 & & \\
\hline
\end{tabular}

Źródło: opracowanie własne na podstawie zgłoszeń oddziałów do uczestnictwa w realizacji projektu, które wpłynęły do ZG PTTK. 


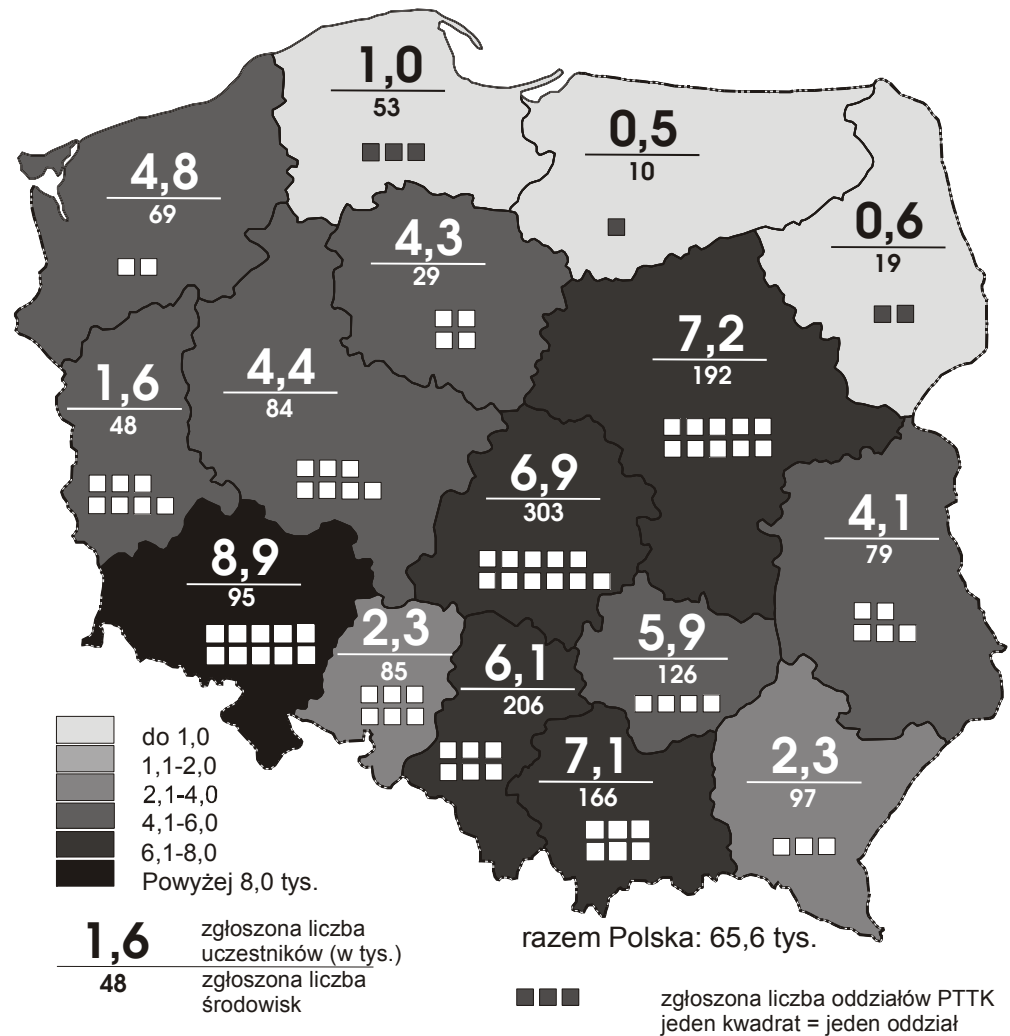

Rys. 2. Udział Wojewódzkich Porozumień Oddziałów PTTK w projekcie Rok Szlaków Turystycznych

Źródło: opracowanie własne na podstawie zgłoszeń oddziałów do uczestnictwa w realizacji projektu, które wpłynęły do ZG PTTK

Od wielu lat na koniec roku sprawozdawczego (31 grudnia każdego roku) Oddziały PTTK sporządzają sprawozdanie (TK-O) ze swojej całorocznej działalności, które składane jest do Głównego Urzędu Statystycznego. W sprawozdaniu tym wartości odnoszące się do turystyki powszechnej i turystyki kwalifikowanej są tymi, które mogłyby posłużyć do zobrazowania zasięgu oddziaływania ${ }^{11}$ projektu na terenie każdego z województw. Aby móc ocenić aktywność turystyczną całego Towarzystwa w tab. 3 umiesz-

11 „Oddziaływanie" - rodzaj działania, które występuje, gdy dwa lub więcej obiektów ma na siebie jakiś wpływ. Różne nauki używają słowa „oddziaływanie” do różnych celów. W socjologii oddziaływanie jest dynamiczną sekwencją działań społecznych pomiędzy jednostkami (lub grupami), które modyfikują własne akcje i reakcje w stosunku do działań partnerów. Określane są one mianem interakcji społecznych (źródło: wikipedia.pl). 
czono dane odnoszące się do turystyki kwalifikowanej i turystyki powszechnej (aktywność turystyczna danego Wojewódzkiego Porozumienia Oddziałów PTTK - zasięg województwa) w 2007 r. Liczbę uczestników biorących udział $\mathrm{w}$ akcji porównano $\mathrm{z}$ aktywnością turystyczną poszczególnych województw pokazując, jaki był procentowy zasięg projektu w każdym z nich.

Tabela 3. Aktywność turystyczna Wojewódzkich Porozumień Oddziałów (WPO) PTTK w 2007 r. w projekcie Rok Szlaków Turystycznych (RST)

\begin{tabular}{|c|c|c|c|c|c|}
\hline \multirow{2}{*}{$\begin{array}{c}\text { Porozumienie } \\
\text { Oddziałów PTTK } \\
\text { Województwa }\end{array}$} & \multicolumn{2}{|c|}{$\begin{array}{l}\text { Aktywność } \\
\text { w turystyce }\end{array}$} & \multirow{2}{*}{$\begin{array}{c}\text { Ogółem } \\
\text { aktywność } \\
\text { turystyczna } \\
\text { WPO PTTK }\end{array}$} & \multirow{2}{*}{$\begin{array}{c}\text { Aktywność } \\
\text { WPO PTTK } \\
\text { w projekcie } \\
\text { RST }\end{array}$} & \multirow{2}{*}{$\begin{array}{c}\text { Udział liczby } \\
\text { uczestników pro- } \\
\text { jektu do ogólnej } \\
\text { aktywności tury- } \\
\text { stycznej } \\
\text { WPO PTTK }\end{array}$} \\
\hline & $\begin{array}{l}\text { kwalifi- } \\
\text { kowanej }\end{array}$ & $\begin{array}{c}\text { pow- } \\
\text { szechnej }\end{array}$ & & & \\
\hline Dolnośląskiego & 51909 & 31457 & 83366 & 8861 & 11 \\
\hline Kujawsko-pomorskiego & 34339 & 10642 & 44981 & 4310 & 10 \\
\hline Lubelskiego & 20170 & 10170 & 30340 & 4092 & 13 \\
\hline Lubuskiego & 10201 & 4871 & 15072 & 1598 & 11 \\
\hline Łódzkiego & 32438 & 7331 & 39769 & 6945 & 17 \\
\hline Małopolskiego & 67058 & 16486 & 83544 & 7100 & 8 \\
\hline Mazowieckiego & 79984 & 50264 & 130248 & 7180 & 6 \\
\hline Opolskiego & 21260 & 9529 & 30789 & 2319 & 8 \\
\hline Podkarpackiego & 17353 & 17759 & 35112 & 2319 & 7 \\
\hline Podlaskiego & 31471 & 3752 & 35223 & 597 & 2 \\
\hline Pomorskiego & 44114 & 19151 & 63265 & 962 & 2 \\
\hline Śląskiego & 108110 & 52906 & 161016 & 7915 & 5 \\
\hline Świętokrzyskiego & 19054 & 12942 & 31996 & 5910 & 18 \\
\hline Warmińsko-mazurskiego & 23105 & 18715 & 41820 & 470 & 1 \\
\hline Wielkopolskiego & 51011 & 35327 & 86338 & 4364 & 5 \\
\hline Zachodniopomorskiego & 23826 & 4536 & 28362 & 4758 & 17 \\
\hline Razem & 635403 & 305838 & 941241 & 69700 & 7 \\
\hline
\end{tabular}

Źródło: opracowanie własne na podstawie sprawozdania TK-O i dokumentacji projektu.

Jak pokazują dane liczbowe (tab. 3, rys. 3), projekt Rok Szlaków Turystycznych nie zdominował całorocznej działalności Towarzystwa ani działań podejmowanych $w$ poszczególnych województwach. Najaktywniejsze w projekcie były województwa: łódzkie, świętokrzyskie i zachodniopomorskie, gdzie $17-18 \%$ osób uczestniczących w zadaniach podejmowanych przez te województwa stanowiły działania związane z projektem. Natomiast najmniejsze zainteresowanie projektem (od 1 do 5\%) można było zaobserwować w województwach: podlaskim, pomorskim, śląskim, warmińsko-ma- 
zurskim i wielkopolskim. Ważną rolę odgrywały w tym przypadku Wojewódzkie Porozumienia Oddziałów PTTK, które miały za zadanie inspirować oddziały i inne zainteresowane instytucje do podejmowania działań w ramach projektu. Nie w każdym województwie zaangażowanie było jednakowe. Do pozytywnie wyróżniających się pod tym względem należały: mazowieckie i wielkopolskie.

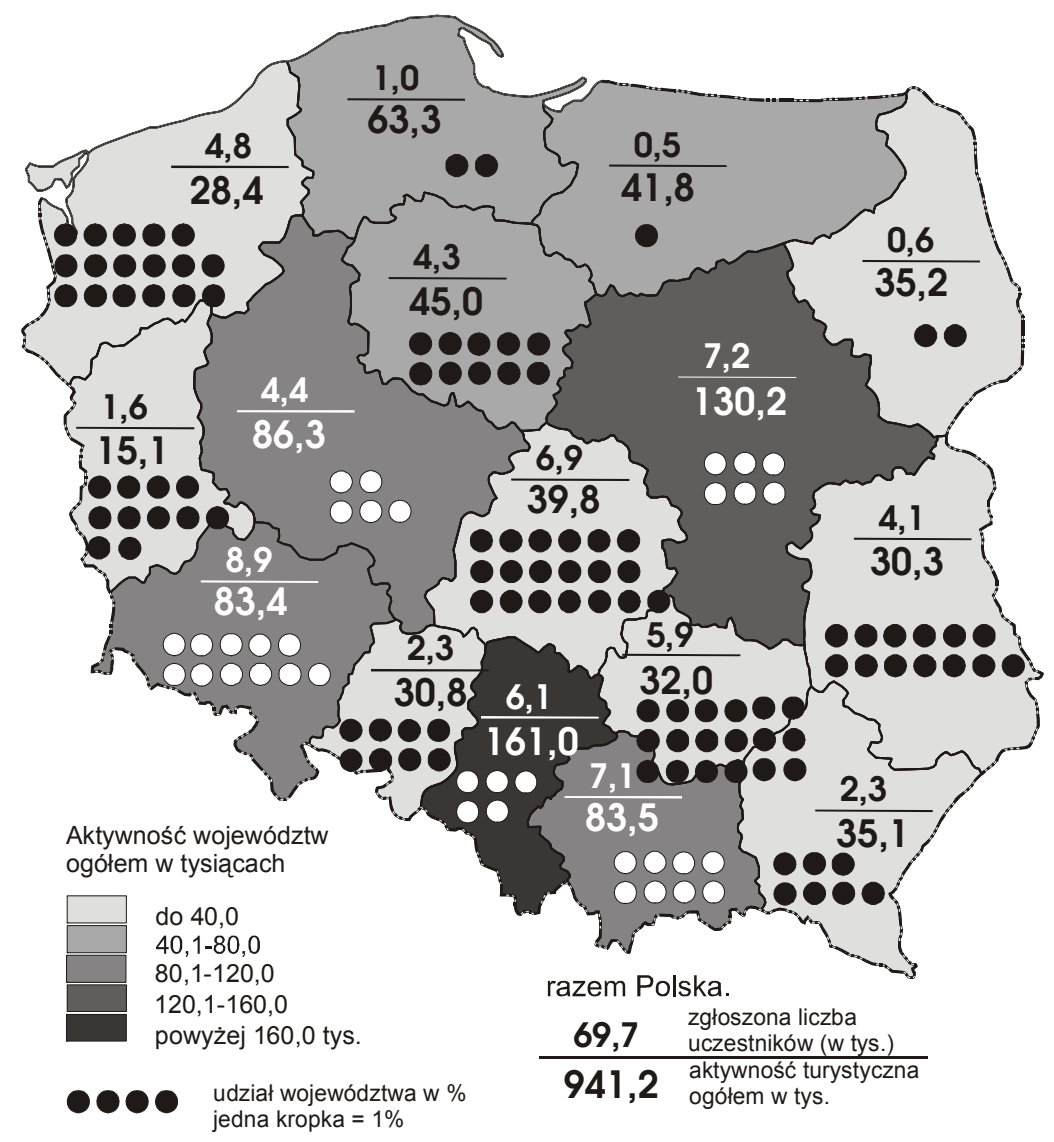

Rys. 3. Uczestnictwo poszczególnych województw w projekcie Rok Szlaków Turystycznych w porównaniu do całorocznej aktywności turystycznej w $2007 \mathrm{r}$. Źródło: opracowanie własne autorki

Analizując sprawozdania, jakie wpłynęły do biura projektu można było zauważyć, że najchętniej uczestniczyły w nim małe środowiska, dla których projekt był swoistą podpowiedzia, co w danym roku można zaproponować 
lokalnej społeczności. Liczne uczestnictwo szkół pokazuje, jak ważne i cenne tematy (m.in. pod względem edukacyjnym) poruszał projekt. W wielu przypadkach propozycje PTTK wypełniały zajęcia pozalekcyjne proponowane przez szkołę, a ich przesłanie edukacyjne „bezpiecznego wędrowania turystycznymi szlakami" było bardzo dobrze przyjmowane zarówno przez dzieci, młodzież, jak i nauczycieli.

Na przykładzie omówionego projektu widać, że pomimo to, iż jest on jedynie dopełnieniem działalności statutowej, to skierowanie go do ogółu społeczności okazało się sukcesem Towarzystwa, które bazując na doświadczeniach z przeprowadzonych wcześniej działań (w tym o charakterze popularyzatorskim i naukowym) każdego roku podejmuje kolejne, nowe wyzwania, wykorzystujące merytoryczny i kadrowy potencjał PTTK.

\section{Trwałe efekty akcji realizowanych przez PTTK}

Trwałym efektem akcji-projektu jest zazwyczaj publikacja pokonferencyjna, będąca swoistym podsumowaniem części działań, która dostarcza wiedzę nie tylko uczelniom wyższym prowadzącym działalność dydaktyczno-naukową w dziedzinie turystyki, ale również organizacjom pozarządowym, ROT-om oraz Regionalnym Pracowniom Krajoznawczym i oddziałom PTTK. Wśród najważniejszych wymienić należy wymienić:

- Szlaki turystyczne a przestrzeń turystyczna (2007, pod red. P. KULECZKI), zawierająca 27 artykułów w działach: O źródłach i realizacji projektu Rok Szlaków Turystycznych PTTK, Polskie szlaki turystyczne w opracowaniach własnych, Historia i stan współczesny wybranych szlaków turystycznych, Z doświadczeń przyjaciół, W kręgu wymiany doświadczeń.

- Rola krajoznawstwa i turystyki w życiu osób niepełnosprawnych (2008, pod red. A. STASIAKA) - 25 artykułów w działach: Turystyka osób niepełnosprawnych w Polsce i za granica, Turystyka i rekreacja osób niepełnosprawnych w badaniach naukowych, Możliwości uprawiania turystyki kwalifikowanej przez osoby niepełnosprawne, Krajoznawstwo i turystyka drogami kształtowania integracji społecznej, Turystyka bez barier dobre praktyki.

- Turystyka zrównoważona i ekoturystyka (2008, pod red. A. GOTOWT- JEZIORSKIEJ i J. ŚLEDZIŃSKIEJ) - 22 artykuły w działach: Funkcjonowanie turystyki i krajoznawstwa na obszarach chronionych, Nowe kierunki w och- 
ronie przyrody, Zrównoważona turystyka - koncepcja, doświadczenia, Podnoszenie świadomości ekologicznej.

- Przyroda uczy najpiękniej - poradnik metodyczno-szkoleniowy (2009, pod red. J. ŚLEDZIŃSKIEJ i A. WIELOCHY) - 14 propozycji edukacji ekologicznej zaprezentowanych przez różnych autorów, w tym sześć dotyczących turystyki osób niepełnosprawnych na obszarach cennych przyrodniczo.

- O potrzebie krajoznawstwa w edukacji szkolnej (2009, pod red. K. DENKA, L. DROŻDŻYŃSKIEGO i A. GORDONA) - 18 artykułów popularnonaukowych.

- Turystyka rodzinna a zachowania prospołeczne (2011, pod red. J. ŚLEDZIŃSKIEJ i B. WŁODARCZYKA) - 30 artykułów w działach: Turystyka rodzinna - charakterystyka zjawiska, Wychowawcze, edukacyjne i zdrowotne aspekty turystyki rodzinnej, Turystyka rodzinna $\mathrm{w}$ regionie, Potencjał i produkty turystyki rodzinnej, Rola i znaczenie PTTK w rozwoju turystyki rodzinnej, Turystyka rodzinna osób niepełnosprawnych (fot. 1).

Ważnymi publikacjami będącymi trwałym śladem zrealizowanych przez

PTTK akcji są opracowania o charakterze popularyzatorskim i praktycznym, $\mathrm{w}$ tym: poradniki, informatory i materiały szkoleniowe, jak np. $\mathrm{z}$ roku:

- 2007 - ABC bezpiecznego wędrowania,

- 2007 - szkolenie e-lerningowe: Wędruj z nami (na CD ),

- 2008 - Informator. (Nie)petnosprawny turysta - wersja drukowana i na CD,

- $2009-A B C$ turysty przyrodnika

- 2009 - szkolenie e-lerningowe: Zostań turysta przyrodnikiem (na CD),

- 2009 - Poradnik. Wybieram wędrowanie (fot. 2),

- 2009 - Bąź turysta przyrodnikiem,

- 2011 - szkolenie e-lerningowe: Od dzidziusia do dziadziusia, czyli wędrować każdy może,

- 2011 - Poradnik. Rodzinne wędrowanie, czyli jak wędrować z dziećmi, aby ich nie zniechęcić do turystyki.

Wszystkie te publikacje są dostępne $\mathrm{w}$ formie PDF na stronach internetowych akcji, a także na stronie www.pttk.pl/publikacje.

Na podkreślenie zasługuje fakt, że wszystkie akcje Towarzystwo organizuje dla ogółu społeczeństwa zainteresowanego konkretną formą turystyki, czy też dziedziną aktywności turystycznej. Odkąd istnieje możliwość pozyskiwania w szerszym zakresie środków zewnętrznych akcje są przeprowadzane z dużym rozmachem i wielotorowo. Od roku 2007 każdy projekt miał zarówno aspekt praktyczny (realizowane konkursy, akcje edukacyjno-szkoleniowe), popularyzatorski (strony internetowe, publikacje poradnikowe), jak i naukowy (konferencje popularnonaukowe, publikacje pokonferencyjne). 


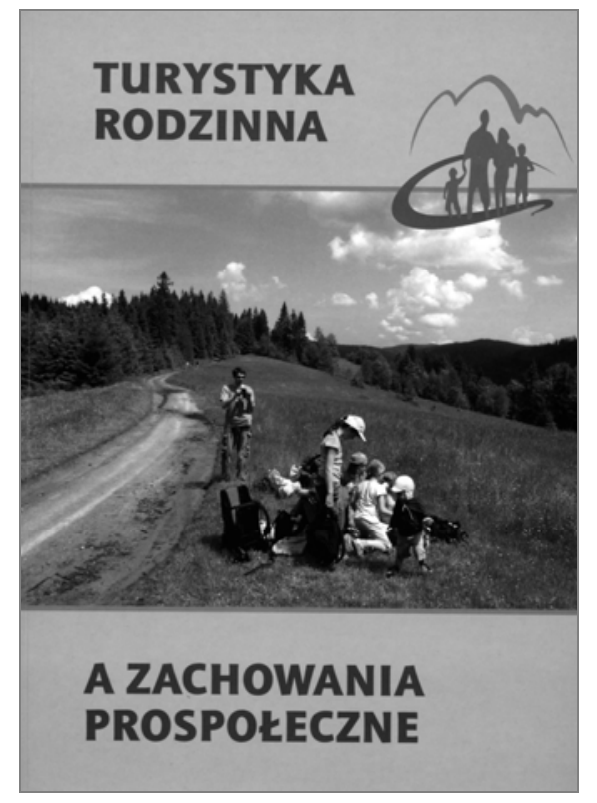

Fot. 1. Rok Turystyki Rodzinnej (2011) okładka monografii naukowej: Turystyka rodzinna zachowania prospołeczne

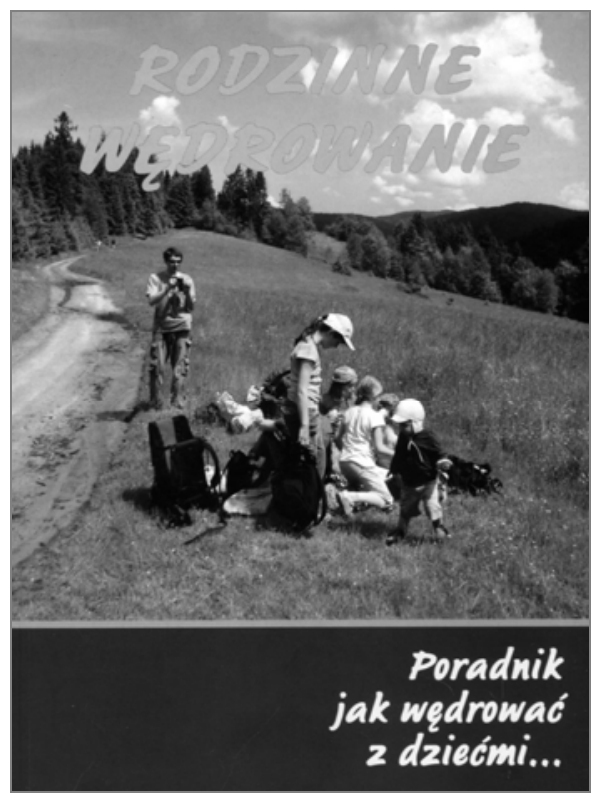

Fot. 2. Rok Turystyki Rodzinnej (2011) okładka: Rodzinne wędrowanie. Poradnik. Jak wędrować z dziećmi...

\section{Konkluzje}

Realizowane od 2007 r. akcje są prowadzone z dużym rozmachem, podejmowanych jest wiele i różnorodnych działań adresowanych do środowisk zainteresowanych m.in. turystyka, krajoznawstwem, ochroną przyrody.

Cele zakładane przez pomysłodawców wpływają na postawy społeczeństwa w zakresie m.in. edukacji na szlakach, ekologicznej, czy też większej otwartości na potrzeby osób niepełnosprawnych.

Pozyskiwane środki umożliwiają dotarcie do liczniejszych grup społecznych, pozwalają wypracować nowe metody działania, pokazują otwartość PTTK na współpracę z innymi instytucjami i osobami niezrzeszonymi w Towarzystwie.

Pierwsza z dofinansowanych ze środków zewnętrznych akcji (Rok Szlaków Turystycznych - 2007) była przedsięwzięciem jednorocznym, jednak doświadczenia nabyte podczas jej realizacji pozwoliły Zarządowi Głównemu 
PTTK na wprowadzenie kolejnych, nowych projektów zakrojonych na szerszą skalę niż te, które były realizowane dotychczas.

Ze względu na możliwość wykorzystania zdobytej wiedzy, doświadczenia i zasobów ludzkich celowe było przeprowadzenie podobnych akcji na terenie Polski w kolejnych latach i dla coraz szerszego grona odbiorców.

Sukcesy dotychczasowych przedsięwzięć umacniają pozycję organizacji i pomagają w pozyskiwaniu środków od kolejnych instytucji i sponsorów na następne działania. Wydane $\mathrm{w}$ ramach projektów publikacje i materiały służą odbiorcom i wytyczają nowe standardy, np. w korzystaniu ze szlaków turystycznych, obszarów cennych przyrodniczo itd. Pokazują również, jak realizować powszechne prawo do turystyki.

Jak wynika z przeprowadzonych badań ankietowych realizowanych podczas ewaluacji projektów, w większości przypadków występuje konieczność dodruku wydawnictw, co świadczy o zainteresowaniu czytelników i dobrej ich ocenie treści w nich zawartych.

Każda z podejmowanych przez Polskie Towarzystwo Turystyczno-Krajoznawcze akcji okazała się sukcesem Towarzystwa, bowiem PTTK jest organizacja, której bogaty program działań adresowany jest nie tylko do jej członków, ale także do innych środowisk zainteresowanych krajoznawstwem i turystyką.

\section{BIBLIOGRAFIA}

Archiwa projektów PTTK: Międzynarodowy rok gór (2002), Europejski rok osób niepetnosprawnych (2003), Spotkania u źródet rzek (2003 i 2004), Rok schronisk górskich PTTK (2004 i 2005), Sadzimy lasy (2005 i 2006), Turystyka dla wszystkich (2006 i 2008), Poznajemy ojczyznę (2006), Rok szlaków turystycznych (2007), Edukacja ekologiczna na szlakach turystycznych(2007), Edukacja ekologiczna kadry programowej PTTK - Natura 2000 (2007), Rok przyrody (2008 i 2009), Rok dzieci i młodzieży (2009), Edukacja ekologiczna kadry programowej PTTK - Natura 2000-II (2009), VI Kongres krajoznawstwa polskiego i Rok wody (2010), Tworzenie wzorców turystyki rodzinnej (2011), Rowerem przez Polske (2012).

DĄBROWSKI P., 2009, ABC turysty przyrodnika, 2009, Wyd. PTTK „Kraj”, Warszawa.

DENEK K., DROŻDŻYŃSKI L., GORDON A. (red.), 2009, O potrzebie krajoznawstwa w edukacji szkolnej, Wyd. PTTK „Kraj”, Warszawa-Poznań.

GOTOWT-JEZIORSKA A., ŚLEDZIŃSKA J. (red.), 2008, Turystyka zrównoważona i ekoturystyka, Wyd. PTTK „Kraj”, Warszawa.

Informator. (Nie)petnosprawny turysta, 2008, Wyd. PTTK „Kraj”, Warszawa, (wersja drukowana i płyta $C D)$.

KAPUŚCIŃSKI J., ZAJĄC M., 2007, ABC bezpiecznego wędrowania, ZG PTTK, Warszawa.

KOPALIŃSKI W., 2006, Podręczny słownik wyrazów obcych, Oficyna Wydawnicza „Rytm”, Warszawa. 
KUleCZKA P. (red.), 2007, Szlaki turystyczne a przestrzeń turystyczna, 2007, Wyd. PTTK „Kraj”, Warszawa.

Od dzidziusia do dziadziusia, czyli wędrować każdy może, 2011, ZG PTTK, Warszawa, płyta CD (szkolenie e-lerningowe).

PIETRASIŃSKI Z., 1982, Sam sięgaj do psychologii, WSP, Warszawa.

SOBOL E. (red.), 2002, Nowy stownik jezzyka polskiego, Wyd. Naukowe PWN, Warszawa.

STASIAK A. (red.), 2008, Rola krajoznawstwa i turystyki w życiu osób niepetnosprawnych, Wyd. PTTK „Kraj”, Warszawa.

SUSKI P., 2002, Stowarzyszenia w prawie polskim, Wyd. Prawnicze „Lexis Nexis”, Warszawa.

ŚLEDZIŃSKA J., WIELOCHA A. (red.), 2009, Bądź turysta przyrodnikiem, Wyd. PTTK „Kraj”, Warszawa.

ŚLEDZIŃSKA J., WIELOCHA A. (red.), 2009, Poradnik. Wybieram wędrowanie, Wyd. PTTK „Kraj”, Warszawa.

ŚLEDZIŃSKA J., WIELOCHA A. (red.), 2009, Przyroda uczy najpiękniej - poradnik metodyczno-szkoleniowy, Wyd. PTTK „Kraj”, Warszawa.

ŚLEDZIŃSKA J., WIELOCHA A. (red.), 2011, Poradnik. Rodzinne wędrowanie, czyli jak wędrować z dziećmi, aby ich nie zniechęcić do turystyki., Wyd. PTTK „Kraj” Warszawa.

ŚLEDZIŃSKA J., WŁODARCZYK B. (red.), 2011, Turystyka rodzinna a zachowania prospołeczne, Wyd. PTTK „Kraj”, Warszawa.

Wędruj z nami 2007, ZG PTTK, Warszawa, płyta CD (szkolenie e-lerningowe).

www.wikipedia.org/wiki/ruch_turystyczny (20.11. 2011).

www.pttk.pl/pttk/przepisy/statut_pttk.pdf (20.11.2011).

www.wiadomosci.ngo.pl (20.11.2011).

www.edueko.pttk.pl.

www.turystykadlawszystkich.pl.

www.rodzina.pttk.pl.

www.narowerze.pttk.pl.

www.cotojest.info(06.2012).

www.spmp.org.pl.

www.wikipedia.pl.

Zostań turysta przyrodnikiem, 2009, ZG PTTK, Warszawa, płyta CD (szkolenie e-lerningowe). 